\title{
COVID-19: The Immune Responses and Clinical Therapy Candidates
}

\author{
Sareh Zhand ${ }^{1,2,{ }^{\dagger}}$, Marie Saghaeian Jazi ${ }^{3,4,+}$, Saeed Mohammadi ${ }^{4,5}$, Roozbeh Tarighati Rasekhi ${ }^{6}$, \\ Ghassem Rostamian ${ }^{7}$, Mohammad Reza Kalani ${ }^{8}$, Aida Rostamian ${ }^{9}$, Jacob George ${ }^{10, *}$ and \\ Mark W Douglas $10,11, *$ (i)
}

1 School of Biomedical Engineering, University of Technology Sydney, Sydney, NSW 2007, Australia; sareh.zhand@uts.edu.au

2 Department of Microbiology, Faculty of Biological Sciences and technology, Shahid Beheshti University, Tehran 1983969411, Iran

3 Metabolic Disorders Research Center, Golestan University of Medcial Sciences, Gorgan 4934174515, Iran; marie.saghaeian@goums.ac.ir

4 Stem Cell Research Center, Golestan University of Medical Sciences, Gorgan 4934174515, Iran; s.mohammadi@goums.ac.ir

5 Infectious Diseases Research Center, Golestan University of Medical Sciences, Gorgan 4934174515, Iran

6 Department of Radiology and Imaging Sciences, School of Medicine, Emory University, Atlanta, GA 30322, USA; roozbeh.rasekhi@emory.edu

7 Reliance GP Super-Clinic, Gosford, NSW 2250, Australia; ghassem.rostamian@reliancehealth.com.au

8 Medical Cellular and Molecular Research Centre, Golestan University of Medical Sciences, Gorgan 4934174515, Iran; kalanimr@yahoo.com

9 Department of Clinical Sciences, Faculty of Veterinary Science, Islamic Azad University of Karaj, Alborz 3149968111, Iran; aida.rostamian@yahoo.com

10 Storr Liver Centre, Westmead Institute for Medical Research, Westmead Hospital and University of Sydney, Sydney, NSW 2145, Australia

11 Centre for Infectious Diseases and Microbiology, Marie Bashir Institute for Infectious Diseases and Biosecurity, University of Sydney at Westmead Hospital, Sydney, NSW 2145, Australia

* Correspondence: jacob.george@sydney.edu.au (J.G.); mark.douglas@sydney.edu.au (M.W.D.)

+ The authors are considered as first author.

Received: 15 July 2020; Accepted: 31 July 2020; Published: 3 August 2020

Abstract: The pandemic of coronavirus disease 2019 (COVID-19), with rising numbers of patients worldwide, presents an urgent need for effective treatments. To date, there are no therapies or vaccines that are proven to be effective against severe acute respiratory syndrome coronavirus 2 (SARS-CoV-2). Several potential candidates or repurposed drugs are under investigation, including drugs that inhibit SARS-CoV-2 replication and block infection. The most promising therapy to date is remdesivir, which is US Food and Drug Administration (FDA) approved for emergency use in adults and children hospitalized with severe suspected or laboratory-confirmed COVID-19. Herein we summarize the general features of SARS-CoV-2's molecular and immune pathogenesis and discuss available pharmacological strategies, based on our present understanding of SARS-CoV and Middle East respiratory syndrome coronavirus (MERS-CoV) infections. Finally, we outline clinical trials currently in progress to investigate the efficacy of potential therapies for COVID-19.

Keywords: SARS-CoV-2; COVID-19; MERS-CoV; SARS-CoV; clinical trial; anti-viral; anti-parasite; molecular immune response; immunotherapy; adjunctive therapy 


\section{Introduction}

The outbreak of severe acute respiratory syndrome coronavirus 2 (SARS-CoV-2) infection has rapidly spread worldwide and produced unprecedented social and economic harm. Coronavirus disease-19 (COVID-19) is an illness caused by this novel coronavirus and can present with symptoms ranging from mild or minimal respiratory symptoms to acute respiratory distress syndrome (ARDS). During the last twenty years, coronaviruses have caused three epidemics of lethal diseases: severe acute respiratory syndrome (SARS), Middle East respiratory syndrome (MERS) and COVID-19. SARS-CoV-2 seems to be less virulent than SARS-CoV or MERS-CoV with mortality rates of $3.4 \%, 9.6 \%$ and $\sim 35 \%$, respectively [1] but appears to be more infectious.

This rapid spread of COVID-19 has generated intense research interest to find a cure or a vaccine. However, there are no Food and Drug Administration (FDA)-approved drugs for the treatment of COVID-19, although remdesivir, an investigational antiviral drug, is available through an FDA emergency use authorization [2]. Several medicines with antiviral or immunomodulatory mechanisms have been recommended as potential investigational therapies, many of which are currently being studied in clinical trials. To date, therapies with proven benefit in certain groups include remdesivir, dexamethasone and convalescent plasma [3-5]. This review describes the structure of SARS-CoV-2, its molecular and immune pathogenesis and summarizes current knowledge about the potential mechanisms for off-label agents widely used to treat COVID-19.

\section{Virology of SARS-CoV-2}

SARS-CoV-2 (about $120 \mathrm{~nm}$ in diameter) is an enveloped, positive-sense single-stranded RNA $(26-32 \mathrm{~kb})$ virus that belongs to the genus Betacoronavirus of the family Coronaviridae in the Nidovirales order. The subgroups of the family are alpha $(\alpha)$, beta $(\beta)$, gamma $(\gamma)$ and delta $(\delta)$ coronaviruses [6]. During the last two decades, several highly pathogenic human coronaviruses have emerged including SARS-CoV in 2002-2003, MERS-CoV in 2012 [1] and SARS-CoV-2 in 2019.

Several phylogenetic analyses of the origin of the SARS-CoV-2 suggests bats are the most likely animal reservoir. Full-genome evolutionary analysis suggests that SARS-CoV-2 is closely related to BatCoV RaTG13 with 96.3\% sequence similarity [7] and two SARS-like coronaviruses derived from bats (bat-SL-CoVZC45 and bat-SL-CoVZXC21) with 88\% similarity, compared to only $79 \%$ and $50 \%$ similarity to SARS-CoV and MERS-CoV, respectively [8] (Figure 1). Transmission of SARS-CoV-2 from bats to humans is likely to have involved an intermediate host, as seen for SARS-CoV (palm civets) and MERS-CoV (dromedary camels). Metagenomic sequencing suggests that Pangolins could be the intermediate hosts due to the genome similarity of Pangolin-associated coronavirus to SARS-CoV-2 (approximately 85.5-92.4\%) [9]. A comprehensive synonymous codon usage (RSCU) bias analysis suggests SARS-CoV-2 might be a recombinant between bat coronavirus and an unknown coronavirus with the same codon usage bias as snake coronavirus [10]. Population genetic analysis of $10^{3}$ SARS-CoV-2 genomes by Tang et al. [11] indicated that this virus has evolved into two main types, $\mathrm{L}$ and $\mathrm{S}$ types. The $\mathrm{L}$ type $(\sim 70 \%)$ is more prevalent than the $\mathrm{S}$ type $(\sim 30 \%)$, due to its higher transmission and/or replication rates, although the $S$ type is older in evolutionary terms [11]. 


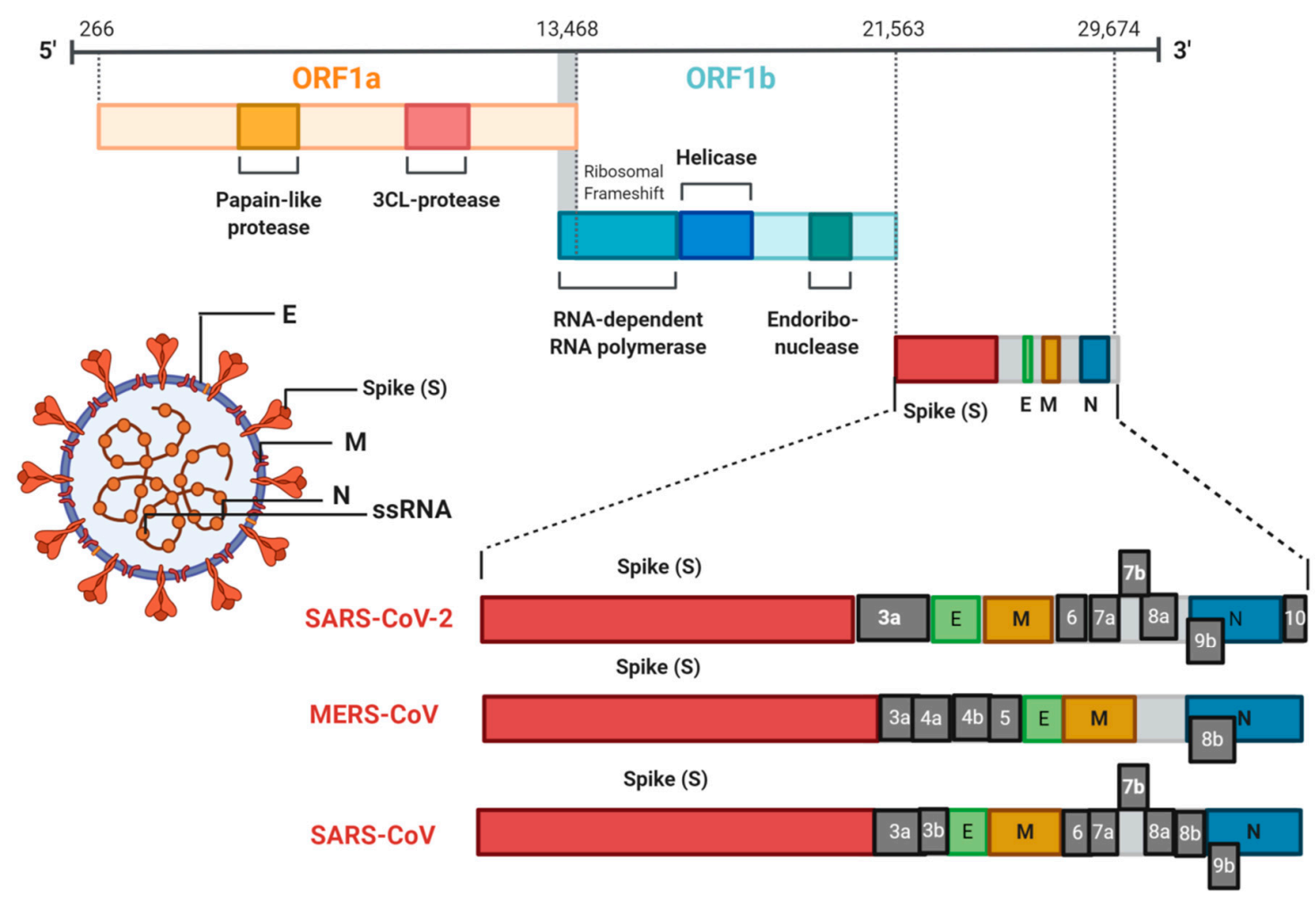

Figure 1. Coronavirus genomic organization. Coronaviruses are enveloped particles $100-160 \mathrm{~nm}$ in diameter with a 26-32 kb single stranded RNA (ssRNA) genome. Severe acute respiratory syndrome coronavirus (SARS-CoV), Middle East respiratory syndrome coronavirus (MERS-CoV) and severe acute respiratory syndrome coronavirus 2 (SARS-CoV-2) share a common open reading frame 1 (ORF1)a/b which encodes a polyprotein. The other ORFs are responsible for coding the four main structural proteins: spike (S), envelope (E), membrane $(\mathrm{M})$ and nucleocapsid (N) proteins plus several accessory proteins.

\section{Coronavirus Entry and Replication}

All coronaviruses have specific genes downstream of the open reading frame 1 (ORF1) that encode for proteins necessary for viral replication and generation of the nucleocapsid and spike proteins [12]. SARS-CoV-2 has 14 ORFs encoding for 27 proteins. ORF1a/b and ORF1a are located at the $5^{\prime}$ end of the SARS-CoV-2 genome and code for the pp1ab and pp1a polyproteins, respectively. These polyproteins contain 15 non-structural proteins (NSP) including NSP1 to NSP10 and NSP 12 to NSP 16. The $3^{\prime}$ end of the genome encodes four structural proteins including spike glycoprotein (S), envelope protein (E), matrix protein $(\mathrm{M})$, nucleocapsid protein $(\mathrm{N})$ and eight accessory proteins (3a, 3b, p6, 7a, 7b, 8b, 9b, and ORF14). Despite similarity in the overall amino acid composition of SARS-CoV-2 and SARS-CoV, remarkable amino acid differences have been identified [13].

The glycoprotein spikes located on the outer surface of coronaviruses work as multifunctional proteins contributing to host receptor binding, cellular tropism and pathogenesis [14]. The amino acid sequence of the SARS-CoV-2 S-protein is $76.47 \%$, similar to that of SARS-CoV, leading to the same structural and electrostatic characteristics at the interaction interface [15]. The S-protein of SARS-CoV-2 resembles a mixture of bat SARS-CoV and an anonymous Beta-CoV [16], with the 3-D structure of the receptor binding domain (RBD) region maintaining similar van der Waals interactions [17].

Both SARS-CoV and SARS-CoV-2 use angiotensin converting enzyme II (ACE2) to enter human and bat cells [18]. The interaction between glutamine 493 in the RBD region of the SARS-CoV-2 spike protein and lysine 31 on the human ACE2 receptor plays an important role in viral binding and entry [19]. Cryo-electron microscopy (Cryo-EM) structure analysis of the spikes shows that the binding efficiency of the SARS-CoV-2 S protein to ACE2 is 10 to 20-fold higher than for SARS-CoV [20]. A single 
N501T mutation in the spike protein of SARS-CoV-2 significantly enhances the binding affinity for its receptor, contributing to the high transmissibility of COVID-19 [19].

The spike protein of coronaviruses forms a trimer that generates a crown-like structure on the envelope, giving this virus family its name (corona $=$ crown) [14]. This large glycoprotein is divided functionally into the S1 and S2 domains. The S1 domain (amino acids 15-680 in SARS-CoV) is responsible for virus binding to its receptor on the target cell and comprises two sub-domains: the N-terminal and the C-terminal of RBD which consists of 193 amino acids (318-510 in SARS-CoV). The S2 domain of the spike protein (amino acids 681-1255 in SARS-CoV) participates in cell membrane fusion $[17,21]$. Cellular proteases including human airway trypsin-like protease (HAT), transmembrane protease serine 2 (TMPRSS2) and cathepsin trigger cleavage of the $S$ protein trimer in SARS-CoV, while furin makes the MERS-CoV S protein competent for fusion. TMPRSS2 is a serine protease localized to the plasma membrane that is responsible for proteolysis of the $S$ protein after receptor-binding [22]. However, the mechanism of enhanced membrane invagination seen during SARS-CoV-2 endocytosis has not been identified [23].

The initial step during SARS-CoV-2 infection is the binding of $S$ to its host receptors, inducing uptake of virus particles by endocytosis and fusion between host and viral membranes [18]. Following membrane fusion and viral entrance, viral genomic RNA is released into the cytoplasm of infected cells. This uncoated RNA acts as a template for translation of the two polyproteins, ppla and pp1ab. The nsp3 and nsp5 encodes two protease enzymes named papain-like proteases (PLpro) and chymotrypsin-like protease (3CLpro) which cleavage between pp1a and pp1ab to form nsps1-11 and 1-16, respectively [24]. A large number of non-structural proteins make the replication-transcription complex (RTC) in double-membrane vesicles. The accessory and structural proteins are generated by translation of a nested set of subgenomic RNAs synthesized by the RTC. Moreover, a negative strand RNA template is transcribed and forms a complex with intermediate products for transcription of positive-sense mRNAs including the progeny genome and subgenomic RNA, mainly mediated by RNA-dependent RNA polymerases (RdRp) [25]. In the infected cell, newly synthesized viral genomic RNA, the structural nucleocapsid and envelope glycoproteins are assembled into viral particles in the endoplasmic reticulum (ER) and Golgi apparatus. In the final step, budding of the viral particles occur through fusion of the plasma membrane and virion-containing vesicles, leading to release of newly formed virions [23].

\section{Pathogenesis of COVID-19}

Although the immunopathogenesis of COVID-19 is not well understood, its clinical symptoms and signs vary from fever and fatigue to severe respiratory complications and multi-organ failure [26]. Understanding the immunopathogenesis of COVID-19 and the differences between affected individuals is essential for designing therapies and decreasing mortality. One approach is to study similar viruses such as SARS-CoV and MERS-CoV and learn from previously described host-pathogen interactions [27].

As discussed, SARS-CoV-2 employs ACE2 as the host cell receptor. ACE2 is highly expressed on many different cell types in a variety of human organs, including lung alveolar epithelial cells and small intestinal epithelial cells, both of which are considered potential SARS-CoV-2 routes of transmission. Overall, ACE2 is expressed widely in the main target organs of SARS-CoV-2, as well as organs that play less important or even unknown roles in COVID-19 pathophysiology [28]. It has been reported that SARS-CoV also infects immune cells such as T lymphocytes, monocytes and macrophages [29], but it remains poorly defined as to what extent SARS-CoV-2 also targets these cells. A number of studies are exploring the immune response to the SARS-CoV-2 [30], with most suggesting that the immune response is disturbed due to aberrant activation of monocytes/macrophages [31], elevation of pro-inflammatory cytokines [32], depletion of lymphocytes [33] and deployment of large numbers of neutrophils [34], but the complex mechanisms involved are still not well understood. 


\section{The Innate Immune Response to SARS-CoV-2 and Virus-Induced Degradation of RNA Sensors}

Similarly to other viral infections, the expression of type I interferons (TI IFN), such as interferon (IFN)- $\alpha$ and IFN- $\beta$, determine the innate immune response to SARS-CoV-2 infection [35]. Pathogen associated molecular patterns (PAMPs) such as viral RNA are sensed by pattern recognition receptors (PRRs) on innate immune cells including antigen presenting cells (APCs), resulting in their activation [36]. Endosomal PRRs including Toll-like receptors (TLR-) 3, 7/8 and 9 are responsible for detection of SARS-CoV-2 [24]. These TLRs are mainly expressed in macrophages and dendritic cells, which are involved in innate immunity [37]. Activation of the TLRs leads to nuclear translocation of NFKB and IFN regulatory factor 3 (IRF3) transcription factors resulting in TI IFN overexpression and the release of pro-inflammatory cytokines (interleukin (IL)-1, IL-6 and Tumor necrosis factor TNF- $\alpha$ ), which have been reported to be overexpressed significantly in SARS-CoV-2 infection in association with "cytokine storm" [37,38]. TI IFNs and these other cytokines also amplify their own expression [39], priming the adaptive immune response or pathogen clearance. However, the inflammatory status can be excessive and is one of the major determinants of COVID-19 disease [27].

In addition to TLRs, several other receptors including RIG-I-like receptors (RLRs) [27], C-type lectin-like receptors (CLRs) [40], NOD-like receptor (NLR) especially NLRP3 inflammasome [41], and free molecule receptors such as STING, cGAS, IFI16 and DAI can be involved in the recognition of viruses and in mediating immune response-related signaling pathways [42]. RLRs are comprised of the H family members RIG-I (DDX58), MDA5 (IFIH), and LGP2 which recognize the genomic structure of RNA viruses such as SARS-CoV-2 [27]. NLRs are a subclass of PRRs which are comprised of a conserved NOD structure and classified into three main categories according to their functions: inflammasome (NLRP1, NLRP3, NLRP6, NLRC4, NLRC5W, and AY2); embryo regenerative and regulatory NLRs [25,41]. CLRs are soluble PRRs mostly expressed in myeloid cells responsible for phagocytosis, maturation of dendritic cells (DCs) and chemotaxis and have been proposed to be associated in SARS-CoV-2 immunopathogenesis [40,43].

Like other viral infections, the SARS-CoV-2 antigens are processed by specific antigen presenting cells (APCs) including macrophages and dendritic cells [44]. The antigens are then presented by major histocompatibility complexes (MHC) or human leukocyte antigens (HLA) to specific cytotoxic $\mathrm{T}$ lymphocytes (CTLs) [45]. It is thought that SARS-CoV-2 relies on MHC I, like SARS-CoV and MERS-CoV, with minimal contribution by MHC II [46]. HLA polymorphisms have been correlated with an altered risk of SARS-CoV and MERS-CoV [47], so it is predicted that polymorphisms in HLA-A, HLA-B, HLA-DR B1, HLA-Cw and HLA-DQB1 could also exert an effect on the immunopathogenesis of SARS-CoV-2 [47].

However, like SARS-CoV and MERS-CoV, SARS-CoV-2 is capable of escaping the immune response [48]. For example, SARS-CoV can successfully shift ubiquitination and enhance degradation of RIG-I/MDA5 RNA sensors, TLR3, TLR7 and TLR8 [49]. Furthermore, SARS-CoV and possibly SARS-CoV-2 can suppress innate immune responses without triggering the anti-viral response machinery, by counteracting NFKB and TI IFN signaling [50]. Moreover, protective immunity against SARS-CoV-2 has not been reported and the virus is capable of immune escape and proliferation in infected organs [36].

\section{Regulation of Adaptive Immune Response in SARS-CoV-2 Infection}

\subsection{T-Cell Mediated Immune Responses Against SARS-CoV-2 and Mechanisms of Immune Escape}

$\mathrm{T}$ lymphocytes play a crucial role in the anti-viral immune response to coronaviruses [32]. Cluster of differentiation CD4+ and CD8+ T cells maintain the balance between the immune response against these pathogens and immune tolerance [51,52]. Antibody-producing B cells are activated by CD4+ T cells, while CD8+ T cells are cytotoxic to virus-infected cells [53]. During SARS-CoV infection, the majority (approximately $80 \%$ ) of inflammatory cells infiltrating the lungs of affected individuals are CD8+ T cells [54] and $\mathrm{T}$ cells can survive in infected tissues [55]. In contrast, CD4+ T cells are more susceptible than CD8+ 
cells to infection by MERS-CoV and SARS-CoV [56]. During SARS-CoV-2 infection, a reduction in the number and quality of $\mathrm{CD} 4+\mathrm{T}$ cells could be associated with decreased activation of B lymphocytes, with reduced levels of virus-specific neutralizing antibodies and pro-inflammatory cytokines (including IL-1 $\beta$, IL-6 and TNF- $\alpha$ ), leading to defective clearance of virus from infected organs [56]. Cooperating with innate immune cells, helper T cells are involved in producing major pro-inflammatory cytokines via NF-kB activation, which is responsible for initiating the production of pro-inflammatory cytokines involved in the cytokine storm [24]. IL-17 produced by Th17 cells mediates the activation of monocytes/macrophages, dendritic cells (DCs) and neutrophils and enhances the production of cytokines (IL-1, LL-6, IL-8, IL-21, TNF- $\alpha$, and Monocyte chemoattractant protein-1 (MCP-1)) from these cells [30]. The possible role of IL-17 and related altered cytokines are highlighted in SARS-CoV-2 infection [57].

One of the important methods that SARS-CoV-2 may use to evade T cell-mediated immune responses is the induction of apoptosis, similar to previous reports in MERS-CoV and SARS-CoV, by enhancing the binding of T-cells to B-cell lymphoma-extra-large (Bcl-xL) molecules [58]. Although this might result in T-cell depletion, recent findings suggest that the $\mathrm{T}$ cell response to structural proteins of coronaviruses (including the $\mathrm{S}, \mathrm{M}$ and $\mathrm{N}$ proteins) persists, providing effective and long-term T-cell responses against COVID-19, which conveys promise for developing vaccines [58].

\subsection{Humoral Immune and Antibody Responses to Coronavirus Infection}

All subtypes of B lymphocytes are involved in the humoral immune response against coronavirus infections [59]. Several antibodies which have been isolated and designated from MERS-CoV and SARS-CoV infected patients are MERS-GD27, CDC-A2, CDC-C2, MCA1, CSC-C5, CDC-A10, and MERS-GD33. We could expect that structurally similar antibodies would be isolated from SARS-CoV-2 patients [60]. The RBD of the SARS-CoV-2 S protein has been identified as an immunodominant and highly specific target for antibodies in affected patients [61]. Since the RBD of the $S$ protein is poorly conserved among SARS-CoVs and other coronaviruses it is a promising antigen for detecting coronavirus specific antibodies, as demonstrated by Premkumar et al. using a large panel of human sera [62,63]. Zost et al. demonstrated that several human monoclonal antibodies (mAbs) targeting the S glycoprotein, including COV-2196 and COV-2130, showed potential neutralizing activity and fully blocked the RBD from interacting with ACE2 [64]. Similarly, epitope mapping by Liu et al. identified a short list of 19 antibodies, equally divided between those targeting the RBD or N-terminal domains, confirming that both are immunogenic [65].

The complement system is an innate immune compartment able to recognize and destroy pathogens that works tightly with the humoral arm of immunity [66]. Viral proteins can mimic host proteins that regulate the complement system, helping the virus to evade immune recognition [67]. C3a and C5a are responsible for the inflammatory response activation of innate immune cells. Thus, inhibiting C3a and C5a during infection with MERS-CoV, SARS-CoV or SARS-CoV-2 could be introduced as promising targets to treat severe lung disease [68].

\subsection{Cytokine Responses Across COVID-19; the Significance of IL-6 in Cytokine Release Syndrome (CRS)}

Although several management strategies are evolving for COVID-19, severe disease results in the ARDS associated with a cytokine release syndrome (CRS). CRS is caused by vast numbers of immune cells producing pro-inflammatory cytokines in a positive feedback loop [69] and is one of the key elements contributing to the mortality and morbidity of COVID-19 [70].

CRS is not specific to SARS-CoV-2 infection and has been demonstrated for MERS-CoV and SARS-CoV, as well as for influenza A subtypes H5N1 and H7N9 [71]. The hallmarks of CRS are elevated serum concentrations of pro-inflammatory cytokines including interleukin-6 (IL-6) and C-reactive protein (CRP) [72]. A meta-analysis of nine different studies demonstrated significantly higher IL-6 levels in people with severe COVID-19 disease than with non-severe disease (mean difference: $38.6 \mathrm{pg} / \mathrm{mL}, 95 \%$ CI: $24.3-52.9 \mathrm{pg} / \mathrm{mL}$ ) and was associated with excess mortality [73].

Binding of SARS-CoV-2 to alveolar epithelial cells activates the immune system, leading to secretion of a large number of cytokines, including IL-6 [74]. IL-6 is an important pro-inflammatory 
and multifunctional cytokine involved in acute inflammation, metabolism, and autoimmune cell differentiation [75]. IL-6 binds to soluble forms of IL-6 receptor (sIL-6R) and forms a complex with gp130 dimers on the cell surface, activating the Janus kinase-signal transducer and activator of transcription 3 (JAK-STAT3) signaling and inducing CRS [74]. Subsequently, vascular endothelial growth factor (VEGF), MCP-1, IL-8, and more IL-6 are secreted, while E-cadherin is downregulated on endothelial cells [76]. The reduction of E-cadherin and VEGF overexpression give rise to increased vascular permeability [77]. IL-6 activates B cells, enhances the expansion and proliferation of T cells, regulates CTL activity, promotes Th17 cell differentiation and inhibits the activation of regulatory $\mathrm{T}$ cells (Tregs) [78]. Tocilizumab is a recombinant humanized monoclonal antibody against human IL-6R $[79,80]$. It has been approved for the treatment of rheumatoid arthritis and systemic juvenile idiopathic arthritis and there is increasing evidence it may be useful for COVID-19 disease [81-83].

Clinical analysis of COVID-19 patients admitted to a hospital in Wuhan, China reported that patients showed elevated plasma concentrations of other cytokines including TNF- $\alpha$, IL-7, IL1 $\beta$, INF $\gamma$, IL1RA and MIP1A/B. Moreover, cytokine levels were higher in patients admitted to the intensive care unit (ICU) [84]. Tumor necrosis factor- $\alpha$ (TNF- $\alpha$ ) is an inflammatory cytokine secreted by activated monocyte/macrophages as part of innate immune system and is directly correlated with COVID-19 disease severity $(R=-0.322$, $p<0.001$ ) [85]. Although targeting TNF- $\alpha$ is rational and appealing, the clinical efficacy of anti-TNF antibodies (e.g., adalimumab) for SARS-CoV-2 infected patients needs further investigation [86].

\section{COVID-19 and Comorbidities}

The clinical presentations of COVID-19 are heterogeneous, so identifying comorbidities associated with COVID-19 is important for several reasons. First, when treating patients, it allows health care providers to adjust and select the best treatment option for vulnerable patients, reducing the risk of side effects due to polypharmacy or drug-drug interactions. Second, it identifies people at higher risk, assisting governments to stratify public health policies and guidelines to allow easing of social distancing restrictions, while protecting the vulnerables. Finally, determining which comorbidities are most associated with poor COVID-19 outcomes will help researchers to understand the pathophysiology of SARS-CoV-2 infection and its interactions with underlying chronic diseases.

Early clinical experience suggested that the elderly and people of any age with serious underlying medical conditions are at a greater risk of severe illness from COVID-19 [87]. Consistent with this, previous studies showed the presence of comorbidities conferred a 3-4 fold increased risk of developing acute respiratory distress syndrome in patients with SARS-CoV [88] and MERS-CoV infections [89]. For COVID-19, medical conditions that put people at increased risk of severe disease include: uncontrolled diabetes; hypertension; lung, liver, and kidney disease; cancer; smoking; solid organ transplant; pregnancy; thalassemia; asthma; neurologic conditions, such as dementia; pulmonary fibrosis (having damaged or scarred lung tissues); obesity and long term steroid therapy [90,91]. A systematic review and meta-analysis of 1576 patients with COVID-19 showed that hypertension $(21.1 \%)$ and diabetes $(9.7 \%)$ were the most prevalent comorbidities, followed by cardiovascular disease (8.4\%) and respiratory disease (1.5\%) [92]. This reflects international studies, which show that comorbidities associated with poor outcomes in COVID-19 include hypertension (20-30\%), diabetes (10-20\%), cardiovascular disease (8-12\%), chronic obstructive pulmonary disease (COPD) (1.5-7.5\%), chronic kidney diseases (1-3\%), cerebrovascular disease (1.5-3\%), co-infection with human immunodeficiency virus (HIV) or hepatitis B virus (1-2\%), malignancy $(1-3.5 \%)$, respiratory illnesses $(1.4 \%)$, renal disorders $(0.5-1.5 \%)$ and immunodeficiencies $(0.01 \%)$ [93-98]. The most common comorbidity varied among the seven countries reviewed, as follows: China (hypertension 39.5\%), South Korea (cardiovascular disease 25.6\%), Italy (hypertension 35.9\%), USA (hypertension 38.9\%), Mexico, (other 42.3\%), UK (hypertension 27.8\%), Iran (diabetes 35.0\%); diabetes was the second most common comorbidity in five of them [93]. Evaluating the mechanisms underlying the associations of severe COVID-19 disease with hypertension, diabetes and respiratory diseases is crucial for the management of high-risk patients and for developing policies and guidelines to reduce future risk of severe COVID-19 disease. Finally, strong precaution should be considered when managing and 
treating COVID-19 patients with preexisting cardiovascular risk factors, especially high blood pressure and diabetes, while patients with uncontrolled hypertension should be informed about their increased risk and advised to take appropriate preventative measures.

\section{Available Treatment Options for COVID-19}

An array of disease modifying drugs have been proposed for the specific treatment of COVID-19 disease and will be discussed below. The classification of drugs and the effective doses are listed in Table 1 while their mechanism of action is illustrated in Figure 2.

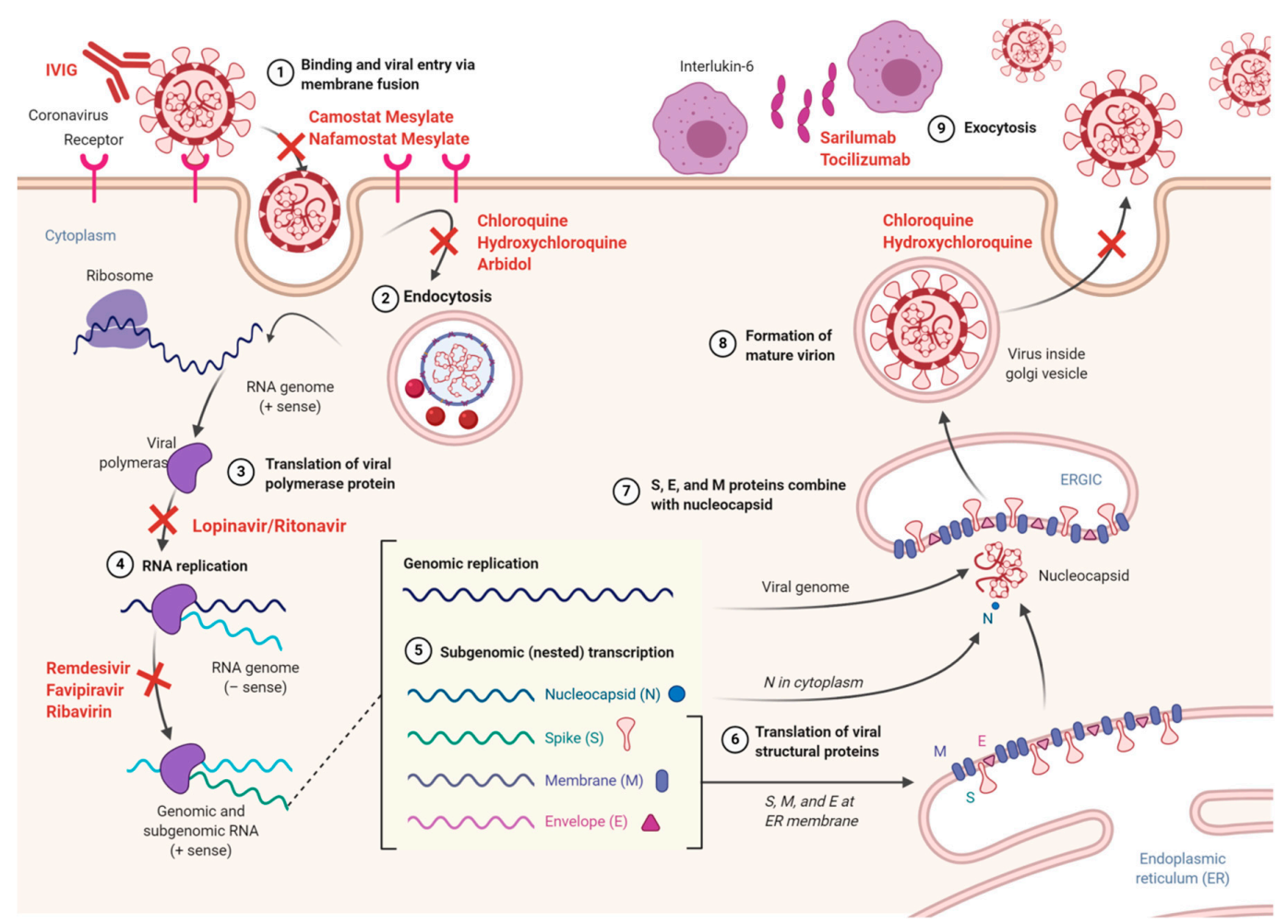

Figure 2. The life cycle of SARS-CoV-2 and potential mechanisms of action of drugs. The virus lifecycle starts when the $S$ protein binds to its cellular receptor angiotensin converting enzyme II (ACE2). Following a conformation change in the $S$ protein, the viral envelope fuses with the cell membrane. After endocytosis, the RNA of SARS-CoV-2 is released to the cytoplasm. Genomic RNA, which is positive sense, is translated into the viral polyproteins pp1a and 1ab. The polymerase produces a series of subgenomic mRNAs and translates the relevant viral proteins. In the endoplasmic reticulum (ER) and Golgi, viral proteins and genome RNA are assembled into virions and transported via vesicles and released out of the cell. ERGIC (ER-Golgi intermediate compartment). Site of action for each therapeutic candidate is shown with red cross.

\subsection{Antivirals}

\subsubsection{Remdesivir}

Remdesivir (RDV) was originally developed as a treatment for Ebola and Marburg virus infection and is a promising candidate for treatment of COVID19. RDV is an adenosine nucleotide analogue with broad-spectrum antiviral activity against RNA viruses including Filoviridae, Paramyxoviridae, Pneumoviridae, and Coronaviridae. It acts as an inhibitor of RdRps and inhibits virus replication through premature termination of RNA transcription as it incorporates into nascent viral RNA chains [99]. Antiviral activity of RDV against coronaviruses including SARS-CoV and MERS-CoV was described in 2017 [100]. Recently, an in vitro study on Vero E6 cells has shown that remdesivir at low-micromolar concentrations blocks SARS-CoV-2 infection with high selectivity (half-maximal 
effective concentration (EC50), $0.77 \mu \mathrm{M}$; half-cytotoxic concentration (CC50) > $100 \mu \mathrm{M}$; SI > 129.87) [101]. Interestingly, remdesivir demonstrated promising results in treatment of the first patient diagnosed with COVID-19 in the United States [102]. In order to further investigate the efficacy and safety of this drug, four clinical trials in severe and mild/moderate respiratory infections by SARS-CoV-2 in the United States and two in China have been commenced [103]. The first randomized controlled clinical trial of remdesivir in the United States, known as the Adaptive COVID-19 Treatment Trial, enrolled 1063 patients and showed that patients who received remdesivir recovered faster, with a median time of 11 rather than 15 days $(p<0.001)$. There was also a non-significant trend towards reduced mortality $(8.0 \%$ in remdesivir arm vs $11.6 \%$ for the placebo arm, $p=0.059)$ [104]. In another cohort of 53 patients hospitalized for severe COVID-19 in the United States, Europe, Canada or Japan a 10-day course of remdesivir resulted in clinical improvement in 36 patients (68\%) [105]. Another randomized, double-blind, placebo-controlled, multicenter trial of remdesivir in 237 laboratory-confirmed SARS-CoV-2 infected patients, from ten hospitals in China (NCT04257656), revealed that time to clinical improvement was not associated with the use of remdesivir; adverse events were reported in $66 \%$ of patients [106]. On May 1st the emergency use of remdesivir for adults and children hospitalized with severe suspected or laboratory-confirmed COVID-19 was approved by the US FDA [4].

\subsubsection{Lopinavir/Ritonavir}

Lopinavir/Ritonavir (LPV/r) is a coformulation of two structurally related protease inhibitor antiretroviral agents primarily used for treatment of HIV-1 infection in adults and children over 2 years of age. LPV/r reduces the replication of SARS-CoV and MERS-CoV in vitro $[107,108]$ by inhibiting viral proteases including 3CLpro or PLpro [108]. Ritonavir is used in combination with Lopinavir to increase LPV half-life by inhibiting Cytochrome P450 3A4 (CYP3A4) [109]. A study of six patients with confirmed COVID-19 infection in Korea and China showed a significant decrease in SARS-CoV-2 viral load and clinical improvement after administration of LPV/r [110,111]. However, concomitant drug therapies, variation in starting time of therapy, different levels of illness severity, and the lack of a control group reinforces the need for caution when interpreting such results $[80,110,111]$. In another study in Singapore the efficacy of LPV/r was evaluated on five patients with COVID-19 who required supplemental oxygen. Three of them improved within 3 days, while two experienced progressive respiratory failure. [112]. On the other hand, in a retrospective cohort study among 29 hospitalized patients who received LPV/r and were discharged, no differences in viral shedding duration was noted [113]. Similarly, Cao et al. reported a clinical trial including 199 patients with SARS-CoV-2 infection, which showed that LPV/r was not associated with clinical improvement [114]. However, the low efficacy of LPV/r in this study might be attributed to the advanced pneumonia in treated patients coupled with a lack of knowledge about the exact concentrations required to inhibit viral replication [115]. So far 10 ongoing clinical trials have been registered from China, Korea, Thailand and Hong Kong to evaluate efficacy of LPV/r for the treatment of COVID-19, either alone or in combination with other antivirals including ribavirin, interferon beta- $1 \mathrm{~b}$ or Chinese traditional medicine [103]. It is important to note that $\mathrm{LPV} / \mathrm{r}$ has significant drug interactions including the risk of cardiac arrhythmia due to QT- prolongation [116]. Cao et al. documented multiple side effects of LPV/r including gastrointestinal adverse events (i.e., anorexia, nausea, abdominal discomfort, or diarrhea) as well as acute gastritis, hepatic injury risk, pancreatitis, more severe cutaneous eruptions, and QT prolongation, and the potential for multiple drug interactions [114]. The European Society of Intensive Care Medicine (ESICM) and the Society of Critical Care Medicine (SCCM) have recommended against the routine use of LPV/r in critically ill COVID-19 patients [117]. The National Institutes of Health (NIH) guidelines recommend against the use of Lopinavir/ritonavir as a clinical benefit has not been demonstrated in patients with COVID-19, due to unfavorable pharmacodynamics and a lack of clinical trials [2]. 


\subsubsection{Favipiravir}

Favipiravir (FPV) is a guanine nucleic acid analogue approved for the treatment of resistant strains of influenza [118]. Intracellular phosphoribosylation of favipiravir generates the active form favipiravir-RTP (favipiravir ribofuranosyl-5B-triphosphate) which is a substrate for the RNA-dependent RNA polymerase of RNA viruses and inhibits polymerase activity [118]. Favipiravir suppresses the replication of flavi-, alpha-, filo-, bunya-, arena-, noro-, and of other RNA viruses [119]. Therefore, favipiravir may also have activity against SARS-CoV-2. The use of favipiravir for COVID-19 has been reported from limited clinical experiences. An open-label study in China compared the effects of favipiravir plus interferon- $\alpha$ with LPV/r plus interferon- $\alpha$ for the treatment of COVID-19. Favipiravir was associated with more rapid viral clearance, better improvement in chest imaging results and less adverse effects [120]. Based on these results favipiravir was approved as the first anti-COVID-19 drug in China [121]. Another randomized clinical trial compared the effect of favipiravir and arbidolol in COVID-19 patients but demonstrated no difference in clinical recovery rate at day 7 . However, favipiravir significantly shortened the latency to relief from pyrexia and cough [122]. An ongoing clinical trial (NCT04303299) is investigating the efficacy, performance and safety of favipiravir in combination with oseltamivir and chloroquine among 80 participants with COVID-19 in Rajavithi Hospital in Thailand; results will be released in November 2020 [123]. There is less preclinical support for favipiravir to treat COVID-19 compared with remdesivir, due to its higher EC50 $(61.88 \mu \mathrm{M})$ compared to remdesevir $(0.77 \mu \mathrm{M})[101,124]$. Favipiravir is well tolerated in healthy volunteers, however caution is required as it is teratogenic [119].

\subsubsection{Ribavirin}

Ribavirin (1- $\beta$-D-ribofuranosyl-1,2,4-triazole-3-carboxamide) is a synthetic guanosine analogue with broad-spectrum activity against several RNA and DNA viruses [125]. It was first approved in 1972 and has been used as a therapeutic agent against respiratory syncytial virus, Lassa fever virus, influenza A and B and in combination with interferon- $\alpha$ for hepatitis C [126]. Ribavirin has multiple mechanisms of action-including interference with RNA capping, inhibition of polymerases, introducing random mutations, suppression of natural guanosine generation by inhibition of inosine monophosphate dehydrogenase and immunomodulatory effects by enhancing the T cell response [127]. The in vitro anti SARS-CoV activity reported for ribavirin differs widely depending on the cell lines used for the antiviral assays. It is possible that ribavirin may be more effective when co-administrated with IFN as this combination inhibited replication of SARS-CoV in five different cell types of animal or human origin, at considerably lower concentrations than with either single treatment alone [128]. Similarly, the combination of IFN $-\alpha 2 b$ and ribavirin in vitro decreased the inhibitory concentration against MERS-CoV to levels that are likely achievable in humans [129]. In terms of SARS-CoV-2, in vitro studies revealed that high concentrations of ribavirin (EC50 of $109.5 \mu \mathrm{M})$ are required to reduce the viral infection and ribavirin is 100 times less potent than remdesivir [101]. Administration of high doses of ribavirin in SARS trials was associated with serious adverse reactions including haemolytic anaemia, electrolyte disturbances and significant teratogenicity. [88,130,131]. Given its considerable adverse effect profile, toxicity and the lack of in vitro data evaluating the efficacy of this compound, the administration of ribavirin for the treatment of COVID-19 is not recommended. An ongoing trial in China (ChiCTR2000029387) is evaluating the efficacy and safety of ribavirin and LPV/ $\mathrm{r}$ in combination with interferon alpha-1b for SARS-CoV-2 infection [132].

\subsubsection{Arbidol Hydrochloride (Umifenovir)}

Arbidol (ARB; ethyl-6-bromo-4-[(dimethylamino) methyl]-5-hydroxy-1-methyl-2-[(phenylthio) methyl]-indole-3-carboxylate hydrochloride monohydrate), an indole derivative, is a broad-spectrum antiviral against various enveloped and non-enveloped viruses and is widely used in Russia and China [133]. Arbidol displays antiviral activity in vitro and/or in vivo against influenza viruses A, B and 
C, adenovirus, respiratory syncytial virus, SARS-CoV, parainfluenza type 5 , poliovirus, rhinovirus 14, coxsackievirus B5, hantavirus, Chikungunya virus, hepatitis B virus (HBV) and hepatitis C virus (HCV) [134]. The anti-viral mechanism of arbidol is thought to relate to inhibition of viral fusion with target cell membranes and with the membranes of endosomes and consequently blockage of virus entry [133]. For influenza A and B viruses it targets hemagglutinin (HA), the major glycoprotein on the surface of the virion, thereby preventing infection [135]. For SARS-CoV, studies have shown direct antiviral effects of arbidol and arbidol mesylate in vitro, with arbidol mesylate reducing the reproduction of SARS-CoV five times more effectively than arbidol [136]. In China, limited clinical experience with arbidol for COVID-19 treatment has been described. In one study from Wuhan in 67 hospitalized patients with confirmed SARS-CoV-2 infection, 36 (53.7\%) received arbidol treatment for a median duration of 9 days and demonstrated lower mortality rates $(0 \%(0 / 36)$ vs. $16 \%(5 / 31))$ and higher discharge rates (33\% (12/36) vs. 19\% (6/31)) compared with patients who did not receive this drug [137]. In a prospective, randomized, controlled, open-label multicenter trial investigating the efficacy of favipiravir compared with arbidol in the treatment of COVID-19 patients, the clinical recovery rate at day 7 did not differ between the favipiravir and arbidol groups [122]. Currently, multiple clinical trials are investigating the efficacy of arbidol on COVID-19 patients in China and USA (NCT04260594, NCT04255017). Four clinical trials are comparing arbidol with oseltamivir, LPV/r and carrimycin for COVID-19 [123].

\subsubsection{Camostat Mesylate (FoipanTM)}

Camostat mesylate (N,N-dimethylcarbamoylmethyl 4-(4-guanidinobenzoyloxy)-phenylacetate) is a synthetic serine protease inhibitor used for the treatment of chronic pancreatitis, dystrophic epidermolysis, oral squamous cell carcinoma and exocrine pancreatic enzyme inhibition [138]. Camostat mesylate was developed in Japan in the 1980s but very little data from outside Japan is available. Some coronaviruses (SARS-CoV, MERS-CoV) and influenza virus activate their envelope glycoproteins by employing host cell proteases [139]. Membrane fusion and host cell entry of SARS-CoV is mediated by spike protein cleavage and activation which requires TMPRSS2, an airway and alveolar cell serine protease [140]. Zhou et al. demonstrated that serine proteases cause the spread of SARS-CoV and camostat effectively prevents this step, suggesting it may be an option for treating SARS and potentially MERS [141]. Another study demonstrated that camostat partially blocked SARS-CoV and human coronavirus NL63 (HCoV-NL63) infection in HeLa cells expressing the ACE2 receptor and TMPRSS2 [142]. Additionally, the effect of camostat mesylate in blocking SARS-CoV-2 infection of human lung Calu-3 cells has been demonstrated [143]. A double-blind randomized controlled clinical trial is evaluating the efficacy of camostat mesylate for treatment of COVID-19 (NCT04353284), but more studies are needed to clarify whether adequate concentrations for suppressing the virus can be attained in a patient's lung.

\subsubsection{Nafamostat Mesylate}

Nafamostat mesylate (6-amidino-2-naphthyl p guanidinobenzoate dimethanesulfonate) is a synthetic serine protease inhibitor available in Japan since 1986 that has been approved for the treatment of inflammatory-related diseases such as pancreatitis [144,145]. Nafamostat is a potent inhibitor of S-mediated membrane fusion of MERS-CoV and blocks MERS-CoV infection in vitro [22]. The anti MERS-CoV activity of nafamostat is through inhibition of the host protease TMPRSS2, which is responsible for the proteolysis of the $S$ protein after the receptor-binding stage [22]. Recently a study in lung cell culture tested the inhibitory effect of gabexate mesylate, nafamostat mesylate and camostat mesylate on SARS-CoV-2 infection and demonstrated that nafamostat mesylate inhibited S-mediated entry of SARS-CoV-2 into host cells 15 times more effectively that camostat mesylate, with an EC50 in the low nanomolar range [146]. In another study, nafamostat was tested in vitro against a clinical SARS-CoV-2 isolate and was shown to have antiviral activity, with an EC50 of $22.50 \mu \mathrm{M}$ [101]. An advantage of targeting host proteases instead of viral protein inhibitors is that it avoids treatment 
failure due to mutations of the target. Despite these promising in vitro data, the efficacy of nafamostat as a COVID-19 treatment needs to be tested in clinical trials.

\subsection{Anti-Parasites}

\subsubsection{Chloroquine/Hydroxychloroquine}

Chloroquine (N4-(7-Chloro-4-quinolinyl)-N1,N1-diethyl-1,4-pentanediamine) has long been used to prevent and treat malaria. It has also been tested in chronic viral diseases and has shown antiviral activity against RNA and DNA viruses including HIV, influenza A and B viruses, influenza A H5N1 virus, $\mathrm{HCV}$, rabies virus, hepatitis A virus, poliovirus, Chikungunya virus, Lassa virus, Dengue virus, Hendra and Nipah viruses, Crimean-Congo hemorrhagic fever virus, Zika virus and Ebola virus, as well as HBV and herpes simplex virus [147]. Sometimes the antiviral activities of chloroquine described in vitro have been confirmed in virus-infected patients, however, the results have not always been reproduced in clinical trials.

Chloroquine possesses different mechanisms of action depending on the pathogen studied. In vitro studies on SARS-CoV showed that chloroquine can interfere with glycosylation of ACE2, in Vero cells [148]. Since SARS-CoV-2 uses a similar receptor, it is expected that chloroquine may prevent SARS-CoV-2 attachment to target cells by the same mechanism. Moreover, chloroquine can induce autophagosome formation resulting in spike protein degradation by changing the $\mathrm{pH}$ of lysosomes and inhibition of cathepsins. Furthermore, chloroquine interferes with viral assembly, budding and proteolytic processing of the M protein through inhibition of Mitogen-activated protein kinases (MAPK) [149].

Previous studies have reported the potential use of chloroquine for treatment of SARS-CoV [150]. The potent efficacy of remdesivir and chloroquine were evaluated in Vero E6; chloroquine was effective in controlling SARS-CoV-2 infection in vitro with an EC50 at $48 \mathrm{~h}$ of $1.13 \mu \mathrm{M}$ [101], comparable with previous in vitro findings against SARS-CoV and MERS-CoV [151]. Besides the antiviral activity of chloroquine, it has immune modulatory functions by inhibition of TNF- $\alpha$ and IL-6 production and secretion. Upon oral administration of chloroquine, it is widely distributed systemically in the body, reaching the lung [101]. There is safety concern in administration of chloroquine due to the risk of macular retinopathy and cardiomyopathy $[152,153]$. Despite the in vitro efficiency of chloroquine, the clinical outcomes are uncertain.

Hydroxychloroquine sulfate, a derivative form of chloroquine, was first synthesized in 1946 by introducing a hydroxyl group into chloroquine. It has two to three times less toxicity in animals compared to chloroquine [154]. Hydroxychloroquine likely has the same mechanism of action on viruses as that of chloroquine and acts as a weak base compound, changing the $\mathrm{pH}$ of endosomes/lysosomes [155].

There is limited published evidence supporting the activity of hydroxychloroquine against coronaviruses. An in vitro study in Vero cells showed that the chloroquine was approximately 5 -fold more potent (EC50 of $6.5 \pm 3.2 \mu \mathrm{M}$ ) than that of hydroxychloroquine (EC50 of $34 \pm 5 \mu \mathrm{M}$ ) against SARS-CoV [156]. Conversely, the potency of hydroxychloroquine in Vero cells infected with SARS-CoV-2 $(\mathrm{EC} 50$ of $0.72 \mu \mathrm{M})$ was greater than that of chloroquine (EC50 of $5.47 \mu \mathrm{M})$ [157]. In a non-randomized open-label trial in France, administration of hydroxychloroquine significantly reduced the viral load in COVID-19 patients, alone or in combination with macrolide antibiotics [158]. However, there are some limitations to the study including small sample size, unclear criteria for enrollment of cases and controls, lack of clinical outcomes as well as enrolment of asymptomatic individuals. Widespread administration of hydroxychloroquine is likely to cause rare adverse effects in patients, including fulminant hepatic failure, serious cutaneous adverse reactions and ventricular arrhythmias (especially when administrated with azithromycin) [159]. It has been shown the combination of hydroxychloroquine and azithromycin in COVID-19 patients is associated with increased risk of QTc prolongation, cardiac dysrhythmias, and death $[160,161]$. Additionally, the FDA does not recommend combination therapy of remdesivir with chloroquine phosphate or hydroxychloroquine sulfate as it might result in a reduced antiviral 
activity of remdesivir [162]. Moreover, the FDA announced the use of hydroxychloroquine and chloroquine for treatment of hospitalized COVID-19 patients can cause serious heart rhythm problems and other safety issues, including blood and lymph system disorders, kidney injuries, liver problems and even liver failure [163]. Owing to the potential side effects—namely heart problems—on June 15th the FDA withdrew the emergency use authorization it issued in March for chloroquine and hydroxychloroquine as COVID-19 treatments. The FDA made this determination based the results from the RECOVERY trial in 1542 hospitalized COVID-19 patients administrated hydroxychloroquine, which found no significant difference in the primary endpoint of 28-day mortality or hospital stay duration $[163,164]$.

At least 16 different trials for SARS-CoV-2 are already registered in the Chinese clinical trial registry (http://www.chictr.org.cn) testing the efficacy of chloroquine and hydroxychloroquine. In addition, hydroxychloroquine is now under evaluation in the U.S. (NCT04308668) as a post-exposure prophylaxis/preemptive therapy for SARS-CoV-2 infection. Recently the NIH guidelines panel for COVID-19 treatment recommended against the use of chloroquine or hydroxychloroquine for the treatment of COVID-19, except in a clinical trial. The panel also recommends against the use of high-dose chloroquine (600 mg twice daily for 10 days) for the treatment of COVID-19 [165].

\subsubsection{Ivermectin}

Ivermectin is an FDA-approved broad spectrum anti-parasitic agent mainly used in the treatment of onchocerciasis, which shows anti-viral effects against HIV-1, simian virus SV40, dengue virus (DENV), West Nile Virus, Venezuelan equine encephalitis virus (VEEV) and Influenza virus [166]. Ivermectin inhibits the interaction between the integrase protein (IN) of HIV-1 and importin (IMP) $\alpha / \beta 1$ heterodimer that is responsible for IN nuclear import [167]. Due to the important role of nuclear transport of viral proteins in the replication cycle as well as inhibition of the host antiviral response, targeting this step might be a therapeutic approach [168]. Recently, a study on Vero-hSLAM cell lines infected with SARS-CoV-2 has shown that ivermectin can reduce viral RNA up to 5000-fold, equal to a $99.98 \%$ reduction after $48 \mathrm{~h}$ [166]. Momekov et al. using available pharmacokinetic data from ivermectin showed that its inhibitory concentrations against the SARS-CoV-2 is unlikely attainable in humans [169]. Overall, the possible efficacy of ivermectin against SARS-CoV-2 infection needs data to support it.

\section{Immunotherapy}

Several studies have been undertaken to develop new treatment strategies for viral infections and the use of immunotherapy is encouraging [170]. One of the most useful immunotherapy methods is passive immunity [171], i.e., the transfer of active humoral immunity including ready-made antibodies. There are two main categories of acquired artificial passive immunity against COVID-19: treatment with monoclonal antibodies (mAbs) and convalescent plasma from people recovering from COVID-19 [171]. The antibodies directly bind to the viral antigen and provide an effective anti-viral response. Several monoclonal antibodies are currently being studied or are undergoing clinical trials [172].

\subsection{Convalescent Plasma Therapy}

Convalescent plasma therapy relies on the administration of plasma from recovered COVID-19 patients. Previous coronavirus outbreaks including SARS-CoV and MERS-CoV as well as Ebola virus disease, avian influenza A (H5N1), 2009 H1N1 pandemic influenza A, respiratory syncytial virus, Zika viruses, human cytomegalovirus and rabies have confirmed the presence of neutralizing antibodies in convalescent serum [173,174]. However, convalescent plasma was not successful for Ebola [175].

Patients with SARS-CoV-2 infection develop a serum antibody response (IgG) to different epitopes of the virus and some of these antibodies have the potential to neutralize the virus. To prepare convalescent 
plasma, plasma rich in IgG antibody is collected at least two weeks after the recovery date [176]. In SARS-CoV-2, passive antibody therapy mediates protection by virus neutralization and perhaps by phagocytosis and/or antibody-dependent cellular cytotoxicity [177]. A study by Duan et al. [3] of 10 adult patients with severe COVID-19 demonstrated that a single dose $(200 \mathrm{~mL})$ of convalescent plasma was not only well tolerated but was able to increase and maintain neutralizing antibodies at a high level. Moreover, clinical and paraclinical symptoms improved within three days and viral RNA was undetectable in blood seven days after the transfusion [3]. Passive antibody therapy is more effective as prophylaxis than for treatment and in infected patients its effectiveness was higher when administered shortly after the appearance of symptoms [177].

In a Hong Kong study, 80 SARS patients who were administrated convalescent plasma before day 14 of disease showed an improved prognosis and a higher discharge rate (58.3\% vs. $15.6 \%$ ), including those who were polymerase chain reaction (PCR) positive and seronegative for SARS-CoV at the time of therapy [178]. Similarly, transfusion of $500 \mathrm{~mL}$ convalescent plasma from three convalescent SARS patients to three health care workers with SARS infection in Taiwan resulted in survival of all three patients, a decrease in viral loads to 0 or 1 copy/mL one day after transfusion and increasing levels of anti-SARS-CoV IgM and IgG [179]. However, administration of convalescent plasma to three patients with MERS in South Korea showed the presence of neutralizing antibodies in only two of them [180]. Concerning COVID-19, Zhang et al. demonstrated anti-SARS-CoV-2 activity of convalescent plasma from six patients in China who had recovered; transfusion of the plasma to a patient with severe COVID-19 resulted in clinical improvement, with no requirement for mechanical ventilation 11 days post-plasma transfusion [181]. Similarly, four critically ill COVID-19 patients who received convalescent plasma and supportive care recovered [104]. The US FDA has approved clinical trials to test the efficacy and safety of plasma from patients recovering from COVID-19 [182-189], joining other registered trials in China, Columbia, Iran, Mexico and Baylor Research Institute in USA [182-189].

\subsection{Intravenous Immunoglobulin (IVIG)}

IVIG is a supportive therapy prepared from pooled plasma of healthy humans. IVIG is traditionally used as replacement therapy in patients with humoral immune deficiencies [190]. Unlike convalescent plasma, IVIG does not contain a SARS-CoV-2 neutralizing antibody [191]. IVIG has various mechanisms of action including interference with B-cell antigen presentation, immune-modulation and immune substitution [192]. During the SARS outbreak, IVIG was used as a therapy, but evidence supporting its effectiveness is inconclusive [193]. Despite some reports on the use of IVIG in MERS infection, there is not any evidence of anti-MERS activity [194]. As these antibodies are administered intravenously, they can cause renal failure or thrombosis in MERS patients [195]. For COVID-19, Shi et al. reported successful treatment of a confirmed patient with advanced respiratory failure, shock and persistent diarrhea, using intensive plasma exchange (PE) and IVIG transfusion [196]. They emphasized the importance of early initiation of PE treatment and IVIG to avoid progression to ARDS and multi-organ failure. Similarly, a multicenter retrospective cohort study of 325 critically unwell adult COVID-19 patients in China who were exposed to IVIG, demonstrated that although early administration improved their prognosis, mortality at 28-days and 60-days was not improved and total duration of disease was longer [197]. In a retrospective study of 58 severe or critical COVID-19 patients in Wuhan treated with IVIG, administration of IVIG within $48 \mathrm{~h}$ of admission to ICU improved prognosis by reducing mechanical ventilation requirement and length of stay [198]. It is important to note that all of these studies were carried out in the context of small sample size and multiple drug treatments; thus, the efficacy and the associated adverse effects of IVIG remain unclear. In order to evaluate the efficacy and safety of IVIG therapy in patients with severe or critical COVID-19, a single-center randomized, open-label, controlled study has been registered (NCT04261426). Like other proposed treatments for COVID-19, IVIG is still unlicensed and insufficient evidence exists to support its use in the management of COVID-19. 


\subsection{Monoclonal Antibodies (mAbs)}

Monoclonal antibodies are synthesized by one unique parental cell and thus bind to a unique epitope. To date, several mAbs have been approved by the FDA for viral infections including SARS-CoV-2 [199]. IL-6 is an attractive target for mAb therapy due to its role in cytokine storm mediated lung inflammation [200], body temperature regulation and fever. In a study on 20 patients with COVID-19 in Anhui, China more than 75\% of patients admitted to ICU who were given tocilizumab showed improvement in oxygen saturation and $90 \%$ reported resolution of lung opacities on CT scans, while CRP decreased in $84 \%$ [80]. In order to compare the efficiency of tocilizumab and favipiravir, a randomized controlled trial has been registered in China (ChiCTR2000030894) [201]. Sarilumab (Kevzara) is another IL-6 receptor antagonist (recombinant humanized anti IL-6R monoclonal antibody) approved for treatment of rheumatoid arthritis [202]. It is currently being evaluated in a Phase 2/3 clinical trial enrolling hospitalized adult COVID-19 patients, sponsored by Sanofi and Regeneron Pharmaceuticals (NCT04315298).

Another inflammatory cytokine involved in COVID-19 disease is TNF- $\alpha$, which can be targeted by mAbs like adalimumab. Currently, there are several trials registered for assessment of adalimumab or biosimilar mAbs (Qletli) for their safety and efficacy in COVID-19 treatment in China (ChiCTR2000030089, ChiCTR2000030580). However, upper respiratory tract infections and reactivation of hepatitis B infection are common and concerning side effects [203].

Baricitinib is an orally administered, JAK antagonist monoclonal antibody used routinely for the treatment of rheumatoid arthritis [204]. Although JAK blockers are considered as potential therapeutic agents in inflammatory storms, several researchers have reported that baricitinib is unlikely to be useful for COVID-19 [205] due to its well-known side effects, including lymphocytopenia and neutropenia, and therefore the risk of viral reactivation [205].

Two other potential mAbs are Leronlimab and Ibalizumab, both of which bind specifically to the $\mathrm{C}-\mathrm{C}$ chemokine receptor type 5 (CCR5). A phase II clinical trial assessing leronlimab in COVID-19 patients with respiratory complications was registered in April 2020 [206]. Ibalizumab is non-immunosuppressive, FDA approved for the treatment of multidrug-resistant HIV in 2018 [207] and may be considered as a co-treatment agent for COVID-19 in the future.

Camrelizumab is a humanized anti programmed death-1 (PD-1) monoclonal antibody. Blocking PD-1 signaling rescues exhausted CD8+T cells and restores their activity during viral infections, but lung toxicity is reported [208]. A clinical trial has been registered using camrelizumab for treatment of critical COVID-19 patients in China [209]. Omalizumab is an IgG1 humanized anti IgE monoclonal antibody that reduces hypersensitivity to allergens and also decreases late inflammation events, so may be considered for COVID-19 patients with dermatologic symptoms [210].

Granulocyte-monocyte colony stimulating factor (GM-CSF) is another immunomodulatory cytokine reported to be present at increased levels in COVID-19 patients [84]. In one clinical trial, adding a single dose of mAb targeting GM-CSF (mavrilimumab) to standard hospital treatment improved clinical outcomes in patients with COVID-19 [211].

The mAbs mentioned above were used to modulate the immune response, but specific human monoclonal antibodies can also be used to neutralize SARS-CoV-2, for both treatment and prevention of COVID-19. Several neutralizing monoclonal antibodies against SARS-CoV and MERS-CoV have potential cross reactivity against SARS-CoV-2 [212]. For example, recent studies showed that a monoclonal antibody (S309) derived from memory B cells from an individual convalescing from SARS-CoV infection are also capable of neutralizing SARS-CoV-2 [213].

By screening hybridomas from immunized mice using pseudotyped vesicular stomatitis virus, a chimeric $\mathrm{mAb}$ called 47D11 was identified which has cross-neutralizing activity against the $\mathrm{S}$ protein from SARS-CoV and SARS-CoV-2. This antibody was subsequently cloned to produce a fully humanized $\mathrm{mAb}$, which in cell culture was able to block SARS-CoV-2 infection [214]. In another study, four mAbs were isolated from individuals who recovered from COVID-19 (B5, B38, H2, and H4), which were able to neutralize SARS-CoV-2 effectively. In particular, B38 and H4 were able to bind 
RBD of the viral S protein, inhibiting its attachment to ACE2 and reducing the virus titer in animal models [215].

\section{Adjunctive/Supportive Therapy}

\subsection{Azithromycin}

Azithromycin (9-deoxo-9a-aza-9a-methyl-9a-homoerythromycin) is a widely used macrolide antibiotic which can inhibit protein synthesis in bacteria by targeting $23 S$ ribosomal RNA. Beside its antibacterial activity, azithromycin has immunomodulatory and anti-viral effects. Previous studies have suggested an antiviral function for azithromycin in Ebola virus infection, both in vitro and in mice [216]. Azithromycin (but not other macrolides like erythromycin or telithromycin) can inhibit rhinovirus replication and release in human bronchial epithelial cells, by inducing expression of interferon and pro-inflammatory cytokines (IL-6 and IL-8) [217]. Azithromycin also shows dose dependent antiviral activity against Zika virus in several cell lines (Vero, Hela, A549, Huh7), inhibiting late stages of virus replication by enhancing the type I and III interferon responses [218]. Interestingly, Tran et al. reported antiviral activity of azithromycin against Influenza (H1N1) virus; treatment prior to infection inhibited virus replication by blocking internalization into host cells, without changing viral attachment [219]. Moreover, intranasal administration of azithromycin to infected mice reduced the viral load in affected lungs [219].

In a non-randomized clinical trial in COVID-19 patients $(n=36)$, Gautret et al. reported that azithromycin co-administered with hydroxychloroquine reduced the viral load more efficiently than hydroxychloroquine alone [158]. Patients were administered hydroxychloroquine (600 mg/day), with or without azithromycin (500 mg day one, followed by $250 \mathrm{mg}$ /day for four days) and SARS-CoV-2 was measured in nasopharyngeal swabs by quantitative reverse transcriptase PCR (qRT-PCR). They found that at day 6 all of the patients in the combination group (6/6) were virologically cured (negative swab), compared to hydroxychloroquine alone (57.1\%) or untreated controls (12.5\%) [158]. However, this small trial was not randomized, patients were not well matched and adding azithromycin to hydroxychloroquine may increase the risk of cardiac arrhythmias. There are now several larger clinical trials investigating the efficacy of azithromycin in COVID-19 patients (e.g., NCT04332107, NCT04336332, NCT04329832), but until these results are available, Azithromycin cannot be recommended for routine use in COVID-19.

\subsection{Corticosteroids}

Corticosteroids are one of the main class of drugs used for chronic inflammatory diseases and immune disorders. Their anti-inflammatory effects are attributed to activating the transcription of anti-inflammatory genes and suppressing pro-inflammatory genes through modulation of histone acetylation [220]. For pneumonia, systemic corticosteroids can be used as an adjuvant to antibiotics, with an analysis of randomized control studies showing that corticosteroids reduce both mortality and morbidity in adults with severe community acquired pneumonia [221].

Inflammatory responses of host immune cells and the resulting cytokine storm are two important aspects of the pathogenesis in severe SARS-CoV-2 infection [222]. However, a meta-analysis of previous observational studies revealed that corticosteroid therapy is associated with increased mortality (Odds Ratio OR $=2.12$ ) in patients with influenza [223] and can delay viral clearance in critically ill MERS patients (adjusted hazard ratio $=0.35$ ) [224]. Another meta-analysis of 15 studies in coronavirus infected patients (including SARS-CoV, SARS-CoV-2 and MERS-CoV) revealed that while corticosteroids are likely to be used in critically ill patients, treatment was associated with increased mortality (Risk Ratio $R R=2.11, p$-value $=0.019)$, increased bacterial infection $(R R=2.08, p<0.001)$ and led to longer hospital stays (total number of patients $=5270$ ) [225]. In an observational study of SARS-CoV-2 infected patients treated with $40 \mathrm{mg}$ methylprednisolone once or twice daily, there was no significant association between corticosteroid treatment and time to viral clearance or length of hospitalization [226]. Similarly, Fang et al. 
reported that low-dose methylprednisolone by injection (median hydrocortisone-equivalent dose, $250 \mathrm{mg} /$ day) or orally (median hydrocortisone-equivalent dose $=237.5 \mathrm{mg} /$ day) had no significant impact on SARS-CoV-2 viral clearance time [227]. Based on these recent results, the World Health Organization (WHO) has not recommended systemic corticosteroids administration for COVID-19 patients outside of clinical trial studies [228]. Indeed, according to the guidelines for COVID-19 patient management released by the Center for Disease Control and Prevention (CDC), corticosteroid treatment is not recommended in confirmed COVID-19 infections except in cases with exacerbation of chronic obstructive pulmonary disease or septic shock [151].

However, recently the randomized evaluation of COVID-19 therapy (RECOVERY) trial (NCT04381936) found that dexamethasone (6 milligrams/day for 10 days) can save lives in intubated COVID-19 patients. Dexamethasone treatment reduced the 28-day mortality by one-third in intubated patients with invasive ventilation and by one-fifth in cases of patients receiving oxygen; however, it was not effective for less severe patients who did not required respiratory support $[229,230]$. Therefore, reflecting its benefit, the NIH COVID-19 treatment guidelines panel recommended administration of dexamethasone $(6 \mathrm{mg} /$ day for up to 10 days) for mechanically ventilated and oxygen supplemented COVID-19 patients. However, the possible adverse effects of secondary infections and hypoglycemia should be considered by the treating clinicians [2].

\subsection{Nitric Oxide}

Nitric Oxide (NO) is a free radical with vasodilator properties. In vascular smooth muscle cells, NO activates soluble guanylate cyclase resulting in production of cyclic guanosine monophosphate (cGMP). The latter, acting as a second messenger, activates cGMP-dependent kinase, leading to reduced cellular calcium level and vasodilation [231]. In vitro studies have reported antiviral activity of the nitric oxide donor compound S-nitroso-N-acetylpenicillamine for inhibition of SARS-Co-V replication in Vero E6 cells [232,233]. Nitric oxide inhalation has also been shown to have long term protective effect (six months after treatment) in ARDS with regard to pulmonary function [234]. Nitric oxide can inhibit both RNA and protein synthesis of SARS-CoV in vitro [232]. Moreover, nitric oxide or its derivatives can inhibit palmitoylation of the viral spike protein, affecting virus binding to its receptor ACE2 and inhibiting SARS-Co-V replication [235]. Nitric oxide inhalation has been successfully used to treat SARS patients, resulting in elevated oxygen saturation, and reduced or discontinued ventilation support [236]. There are several clinical trials currently investigating the therapeutic potential of nitric oxide therapy in patients with COVID-19 (NCT04358588, NCT04305457), as more data are required to confirm its effectiveness. 
Table 1. List of available drugs targeting SARS-CoV-2 infection and their effective dosage.

\begin{tabular}{|c|c|c|c|c|c|}
\hline Name of Medicine & Target & Classification & Effective Dosage & Registered Clinical Trial & Reference \\
\hline Remdesivir & Viral RNA polymerase & Anti-viral & $\begin{array}{l}\text { IV injection } 200 \mathrm{mg} \text { at day first, } \\
100 \mathrm{mg} \text { for } 9 \text { days }\end{array}$ & $\begin{array}{c}\text { NCT04257656, NCT04252664, } \\
\text { NCT04292730, NCT04315948, } \\
\text { NCT04321616 }\end{array}$ & [237] \\
\hline Lopinavir/Ritonavir & Viral protease & Anti-viral & $\begin{array}{c}\text { Oral administration } 400 \mathrm{mg} \text { lopinavir } \\
\text { and } 100 \mathrm{mg} \text { ritonavir twice a day for } \\
14 \text { days, peroral }\end{array}$ & $\begin{array}{c}\text { ACTRN12620000445976, NCT02735707, } \\
\text { ISRCTN83971151, NCT04321174, } \\
\text { NCT04350684, ISRCTN50189673, } \\
\text { NCT04315948, NCT04328012, } \\
\text { NCT04276688, ISRCTN50189673, } \\
\text { NCT04321993 }\end{array}$ & [114] \\
\hline Favipiravir & Viral RdRP & Anti-viral & $\begin{array}{l}\text { Oral administration } 1600 \mathrm{mg} \text { twice } \\
\text { daily on first day and } 600 \mathrm{mg} \text { twice a } \\
\text { day on day } 2-14 .\end{array}$ & $\begin{array}{l}\text { 2020-001435-27, NCT04359615, } \\
\text { NCT04303299, NCT04402203 }\end{array}$ & [120] \\
\hline Ribavirin & viral RNA & Anti-viral & $\begin{array}{c}500 \mathrm{mg} \text { each time, } 2 \text { to } 3 \text { times/day in } \\
\text { combination with IFN- } \alpha \text { or } \\
\text { lopinavir/ritonavir }\end{array}$ & $\begin{array}{l}\text { NCT04276688, NCT04392427, } \\
\text { ChiCTR2000029387 }\end{array}$ & [238] \\
\hline Arbidol & Viral RNA polymerase & Anti-viral & $\begin{array}{l}200 \mathrm{mg} \text { three times a day for a } \\
\text { duration of } 7-14 \text { days }\end{array}$ & $\begin{array}{l}\text { NCT04260594, NCT04350684, } \\
\text { NCT04255017 }\end{array}$ & [239] \\
\hline Nafamostat & TMPRSS2 & Anti-viral & $240 \mathrm{mg}$ daily, for 5 days, peroral & NCT04418128 & [138] \\
\hline $\begin{array}{l}\text { Chloroquine } \\
\text { Phosphate }\end{array}$ & ACE2 & Anti-parasite & $\begin{array}{l}500 \mathrm{mg} \text { (300 mg for chloroquine) each } \\
\text { time, } 2 \text { times/day }\end{array}$ & $\begin{array}{l}\text { NCT04303507, NCT04324463, } \\
\text { NCT04353336, NCT04328493 }\end{array}$ & [238] \\
\hline Hydroxychloroquine & Endosome, $\mathrm{pH}$ elevation & Anti-parasite & $\begin{array}{l}200 \mathrm{mg} \text {, three times per day for } \\
\text { ten days }\end{array}$ & $\begin{array}{c}\text { NCT04261517, NCT04308668, } \\
\text { NCT02735707, ISRCTN83971151, } \\
\text { NCT04315948, NCT04321616, } \\
\text { NCT04350684 }\end{array}$ & {$[158,239]$} \\
\hline IVIG & immune modulation & Immunoglobulin & $\begin{array}{l}400 \mathrm{mg} / \mathrm{kg} \text { for a duration of five days } \\
\text { in children }\end{array}$ & NCT04411667, NCT04261426 & [241] \\
\hline Ivermectin & $\begin{array}{l}\text { Inhibition of nuclear } \\
\text { transport }\end{array}$ & Anti-parasite & $\begin{array}{l}\text { Oral administration } 600 \mu \mathrm{g} / \mathrm{kg} \text { ) daily } \\
\text { for } 3 \text { days }\end{array}$ & NCT04343092, NCT04392427 & [242] \\
\hline Tocilizumab & $\begin{array}{l}\text { IL-6 receptor subunit } \\
\text { alpha }\end{array}$ & $\begin{array}{l}\text { Monoclonal } \\
\text { antibody }\end{array}$ & $\begin{array}{l}400 \mathrm{mg} \text { intravenous or } 8 \mathrm{mg} / \mathrm{kg} \times 1-2 \\
\text { doses. Second dose } 8-12 \mathrm{~h} \text { after first } \\
\text { dose if inadequate response. }\end{array}$ & NCT04335071, ChiCTR2000030894 & [239] \\
\hline
\end{tabular}


Table 1. Cont.

\begin{tabular}{|c|c|c|c|c|c|}
\hline Name of Medicine & Target & Classification & Effective Dosage & Registered Clinical Trial & Reference \\
\hline Azitromycin & $23 S$ rRNA & Anti-microbial & $\begin{array}{c}500 \mathrm{mg} \text { on day } 1 \text { followed by } \\
250 \mathrm{mg} / \text { day for the next four days (in } \\
\text { combination with } \\
\text { hydroxychloroquine }\end{array}$ & $\begin{array}{l}\text { NCT04359316, NCT04332107, } \\
\text { NCT04336332, NCT04329832 }\end{array}$ & [158] \\
\hline Corticosteroides & $\begin{array}{l}\text { Binds glucocorticoid } \\
\text { receptor and suppress } \\
\text { inflammation }\end{array}$ & Anti-Inflammation & $\begin{array}{l}40 \mathrm{mg} \text { methylprednisolone once or } \\
\text { twice daily }\end{array}$ & NCT04273321 & [226] \\
\hline Dexamethasone & $\begin{array}{l}\text { Binds glucocorticoid } \\
\text { receptor and suppress } \\
\text { inflammation }\end{array}$ & Anti-Inflammation & 6 milligrams/day for 10 days & ISRCTN50189673, NCT04381936 & [243] \\
\hline Nitricoxide & Activates cGMP & vasodilator & $\begin{array}{l}\text { For SARS patients; Inhalation for } \\
\geq 3 \text { days ( } 30 \text { ppm on day } 1,20 \text { and } \\
10 \text { ppm on days } 2 \& 3 \text { ) }\end{array}$ & $\begin{array}{l}\text { NCT04383002, NCT04338828, } \\
\text { NCT04358588, NCT04305457 }\end{array}$ & [236] \\
\hline
\end{tabular}

TMPRSS2, transmembrane protease serine 2; ACE2, angiotensin converting enzyme II, IFN- $\alpha$, interferon- $\alpha$. 


\section{Conclusions and Future Directions}

Diverse antiviral drugs with proven activity against influenza virus, SARS or MERS coronaviruses have been investigated for the treatment of COVID-19, alone or in combination with other drugs (anti-parasitic agents, anti-inflammatory drugs). Of these, remdesivir has been approved by the FDA for emergency use in adults and children hospitalized with severe, suspected or laboratory-confirmed COVID-19. Moreover, the NIH panel recommends remdesivir for treatment of COVID-19 in patients who are on mechanical ventilation or extracorporeal membrane oxygenation (ECMO) [2]. Dexamethasone treatment showed promising results in reducing the 28-day mortality in intubated patients and in cases receiving oxygen. The WHO reported that it could be lifesaving for critically ill COVID-19 patients and the NIH panel recommends using dexamethasone at proven doses in COVID-19 patients who are mechanically ventilated, as well as in patients who require supplemental oxygen but are not mechanically ventilated [2].

Early data on administration of hydroxychloroquine often in combination with azithromycin were promising, however studies were very low quality, with methodological concerns raised including small subject numbers, poor study design, the absence of appropriate controls and end points of unclear utility. Therefore, on 4 July 2020 the WHO accepted the recommendation from the Solidarity Trial's International Steering Committee to discontinue the hydroxychloroquine arm in the trial. The fusion inhibitor umifenovir and protease inhibitor lopinavir/ritonavir were also regarded initially as likely effective candidates to treat COVID-19. However, the NIH panel now recommends against the use of chloroquine, hydroxychloroquine, Lopinavir/ritonavir or non-SARS-CoV-2-specific intravenous immune globulin (IVIG) for the treatment of COVID-19, except in a clinical trial. Furthermore, NIH does not recommend either for or against the use of COVID-19 convalescent plasma, SARS-CoV-2 immune globulin or Interleukin-6 inhibitors (e.g., sarilumab, siltuximab, tocilizumab) for the treatment of COVID-19, due to insufficient data.

The constantly changing recommendations from major international health bodies highlights the challenges of treating a novel deadly pathogen in the midst of a rapidly escalating pandemic. However, it also reinforces the importance of undertaking large, well designed clinical trials to evaluate potential treatments, instead of relying on preliminary unpublished data or the latest rumors on social media. The widespread empiric use of unproven agents such as hydroxychloroquine can lead to supply shortages for people who rely on the drug, potentially life-threatening side effects, and delays in evaluating its true clinical efficacy, along with that of other potential therapies. Many large trials are now underway to assess both novel and repurposed drugs to treat COVID-19, and their outcomes are eagerly awaited. Given the scale of the pandemic even incremental improvements can save thousands of lives, while we await the development of potent antiviral agents, targeted immunotherapies or an effective vaccine.

Author Contributions: Conceptualization: G.R., R.T.R., S.Z.; writing_original draft preparation: S.Z., M.S.J., S.M., R.T.R., G.R., M.R.K., A.R.; writing—review and editing: S.Z., M.S.J., S.M., R.T.R., G.R., M.R.K., A.R., J.G., M.W.D.; supervision: J.G., M.W.D.; manuscript revision: J.G., M.W.D., S.Z., S.M. All authors have read and agreed to the published version of the manuscript.

Funding: Jacob George and Mark Douglas were supported by the Robert W. Storr Bequest to the Sydney Medical Foundation, University of Sydney; National Health and Medical Research Council of Australia (NHMRC) Program Grant (1053206) and Project grants (APP1107178 and APP1108422).

Conflicts of Interest: The authors declare no conflict of interest.

\section{Abbreviations}

COVID-19 Coronavirus disease 2019

SARS-CoV-2 severe acute respiratory syndrome coronavirus 2

FDA US Food and Drug Administration

MERS-CoV Middle East respiratory syndrome coronavirus

ARDS acute respiratory distress syndrome 


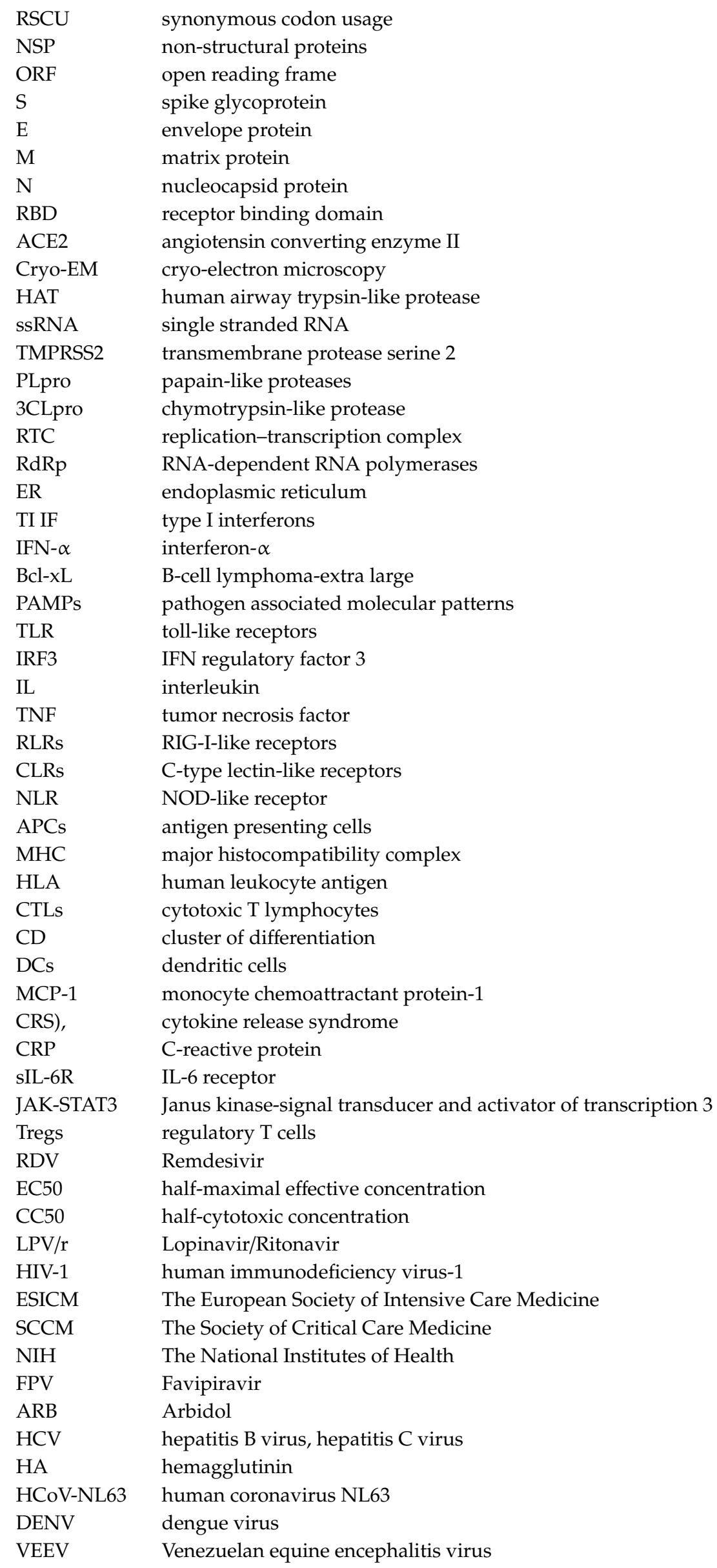




$\begin{array}{ll}\text { IN } & \text { integrase protein } \\ \text { IMP } & \text { importin } \\ \text { mAbs } & \text { monoclonal antibodies } \\ \text { ERGIC } & \text { ER-Golgi intermediate compartment } \\ \text { IVIG } & \text { intravenous immunoglobulin } \\ \text { PE } & \text { plasma exchange } \\ \text { ICU } & \text { intensive care unit } \\ \text { PCR } & \text { polymerase chain reaction } \\ \text { qRT-PCR } & \text { quantitative reverse transcriptase PCR } \\ \text { WHO } & \text { World Health Organization } \\ \text { PD-1 } & \text { programmed death-1 } \\ \text { CDC } & \text { left for disease control and prevention } \\ \text { NO } & \text { nitric oxide } \\ \text { cGMP } & \text { cyclic guanosine monophosphate } \\ \text { GM-CSF } & \text { granulocyte-monocyte stimulating factor }\end{array}$

\section{References}

1. De Wit, E.; Van Doremalen, N.; Falzarano, D.; Munster, V.J. SARS and MERS: Recent insights into emerging coronaviruses. Nat. Rev. Genet. 2016, 14, 523-534. [CrossRef] [PubMed]

2. NIH. Potential Antiviral Drugs Under Evaluation for the Treatment of COVID-19. Available online: https://www.covid19treatmentguidelines.nih.gov/antiviral-therapy/ (accessed on 24 July 2020).

3. Duan, K.; Liu, B.; Li, C.; Zhang, H.; Yu, T.; Qu, J.; Zhou, M.; Chen, L.; Meng, S.; Hu, Y.; et al. Effectiveness of convalescent plasma therapy in severe COVID-19 patients. Proc. Natl. Acad. Sci. USA 2020, 117, 9490-9496. [CrossRef] [PubMed]

4. Administration UFad. Coronavirus (COVID-19) Update: FDA Issues Emergency Use Authorization for Potential COVID-19 Treatment. Available online: https://www.fda.gov/news-events/press-announcements/ coronavirus-covid-19-update-fda-issues-emergency-use-authorization-potential-covid-19-treatment (accessed on 1 May 2020).

5. Chaib, F. WHO Welcomes Preliminary Results about Dexamethasone Use in Treating Critically Ill COVID-19 Patients. World Health Organization. Available online: https://www.who.int/news-room/detail/16-06-2020who-welcomes-preliminary-results-about-dexamethasone-use-in-treating-critically-ill-covid-19-patients (accessed on 16 June 2020).

6. Shereen, M.A.; Khan, S.; Kazmi, A.; Bashir, N.; Siddique, R. COVID-19 infection: Origin, transmission, and characteristics of human coronaviruses. J. Adv. Res. 2020, 24, 91-98. [CrossRef] [PubMed]

7. Paraskevis, D.; Kostaki, E.; Magiorkinis, G.; Panayiotakopoulos, G.; Sourvinos, G.; Tsiodras, S. Full-genome evolutionary analysis of the novel corona virus (2019-nCoV) rejects the hypothesis of emergence as a result of a recent recombination event. Infect. Genet. Evol. 2020, 79, 104212. [CrossRef]

8. Lu, R.; Zhao, X.; Li, J.; Niu, P.; Yang, B.; Wu, H.; Wang, W.; Song, H.; Huang, B.; Zhu, N.; et al. Genomic characterisation and epidemiology of 2019 novel coronavirus: Implications for virus origins and receptor binding. Lancet 2020, 395, 565-574. [CrossRef]

9. Lam, T.T.; Shum, M.H.-H.; Zhu, H.-C.; Tong, Y.-G.; Ni, X.-B.; Liao, Y.-S.; Wei, W.; Cheung, W.Y.-M.; Li, W.-J.; Li, L.-F.; et al. Identification of 2019-nCoV related coronaviruses in Malayan pangolins in southern China. BioRxiv 2020. [CrossRef]

10. Ji, W.; Wang, W.; Zhao, X.; Zai, J.; Li, X. Cross-species transmission of the newly identified coronavirus 2019-nCoV. J. Med. Virol. 2020, 92, 433-440. [CrossRef]

11. Tang, X.; Wu, C.; Li, X.; Song, Y.; Yao, X.; Wu, X.; Duan, Y.; Zhang, H.; Wang, Y.; Qian, Z.; et al. On the origin and continuing evolution of SARS-CoV-2. Natl. Sci. Rev. 2020, 7, 1012-1023. [CrossRef]

12. Van Boheemen, S.; De Graaf, M.; Lauber, C.; Bestebroer, T.M.; Raj, V.S.; Zaki, A.M.; Osterhaus, A.D.; Haagmans, B.L.; Gorbalenya, A.E.; Snijder, E.J.; et al. Genomic Characterization of a Newly Discovered Coronavirus Associated with Acute Respiratory Distress Syndrome in Humans. mBio 2012, 3, e00473-12. [CrossRef] 
13. Wu, A.; Peng, Y.; Huang, B.; Ding, X.; Wang, X.; Niu, P.; Meng, J.; Zhu, Z.; Zhang, Z.; Wang, J.; et al. Genome Composition and Divergence of the Novel Coronavirus (2019-nCoV) Originating in China. Cell Host Microbe 2020, 27, 325-328. [CrossRef]

14. Sigrist, C.J.; Bridge, A.; Le Mercier, P. A potential role for integrins in host cell entry by SARS-CoV-2. Antivir. Res. 2020, 177, 104759. [CrossRef] [PubMed]

15. Wang, H.; Li, X.; Li, T.; Zhang, S.; Wang, L.; Wu, X.; Liu, J. The genetic sequence, origin, and diagnosis of SARS-CoV-2. Eur. J. Clin. Microbiol. Infect. Dis. 2020, 1. [CrossRef] [PubMed]

16. Walls, A.C.; Park, Y.J.; Tortorici, M.A.; Wall, A.; McGuire, A.T.; Veesler, D. Structure, Function, and Antigenicity of the SARS-CoV-2 Spike Glycoprotein. Cell 2020, 181, 281-292. [CrossRef] [PubMed]

17. He, Y.; Zhou, Y.; Liu, S.; Kou, Z.; Li, W.; Farzan, M.; Jiang, S. Receptor-binding domain of SARS-CoV spike protein induces highly potent neutralizing antibodies: Implication for developing subunit vaccine. Biochem. Biophys. Res. Commun. 2004, 324, 773-781. [CrossRef]

18. Zhou, P.; Yang, X.-L.; Wang, X.-G.; Hu, B.; Zhang, L.; Zhang, W.; Si, H.-R.; Zhu, Y.; Li, B.; Huang, C.-L.; et al. A pneumonia outbreak associated with a new coronavirus of probable bat origin. Nature 2020, 579, 270-273. [CrossRef]

19. Wan, Y.; Shang, J.; Graham, R.; Baric, R.S.; Li, F. Receptor Recognition by the Novel Coronavirus from Wuhan: An Analysis Based on Decade-Long Structural Studies of SARS Coronavirus. J. Virol. 2020, 94. [CrossRef]

20. Wrapp, D.; Wang, N.; Corbett, K.; Goldsmith, J.A.; Hsieh, C.-L.; Abiona, O.; Graham, B.S.; McLellan, J.S. Cryo-EM structure of the 2019-nCoV spike in the prefusion conformation. Science 2020, 367, 1260-1263. [CrossRef]

21. Kim, H.; Hong, Y.; Shibayama, K.; Suzuki, Y.; Wakamiya, N.; Kim, Y.U. Functional analysis of the receptor binding domain of SARS coronavirus S1 region and its monoclonal antibody. Genes Genom. 2014, 36, 387-397. [CrossRef]

22. Yamamoto, M.; Matsuyama, S.; Li, X.; Takeda, M.; Kawaguchi, Y.; Inoue, J.-I.; Matsuda, Z. Identification of Nafamostat as a Potent Inhibitor of Middle East Respiratory Syndrome Coronavirus S Protein-Mediated Membrane Fusion Using the Split-Protein-Based Cell-Cell Fusion Assay. Antimicrob. Agents Chemother. 2016, 60, 6532-6539. [CrossRef]

23. Guo, Y.-R.; Cao, Q.-D.; Hong, Z.; Tan, Y.-Y.; Chen, S.; Jin, H.; Tan, K.S.; Wang, D.Y.; Yan, Y. The origin, transmission and clinical therapies on coronavirus disease 2019 (COVID-19) outbreak-An update on the status. Mil. Med. Res. 2020, 7, 11-110. [CrossRef]

24. Astuti, I.J.D. Research MSC, Reviews. Severe Acute Respiratory Syndrome Coronavirus 2 (SARS-CoV-2): An overview of viral structure and host response. Diabetes Metab. Syndr. 2020, 14, 407-412. [CrossRef]

25. Chen, Y.; Liu, Q.; Guo, D. Emerging coronaviruses: Genome structure, replication, and pathogenesis. J. Med. Virol. 2020, 92, 418-423. [CrossRef] [PubMed]

26. Qin, C.; Zhou, L.; Hu, Z.; Zhang, S.; Yang, S.; Tao, Y.; Xie, C.; Ma, K.; Shang, K.; Wang, W.; et al. Dysregulation of Immune Response in Patients with COVID-19 in Wuhan, China. SSRN Electron. J. 2020. [CrossRef]

27. Prompetchara, E.; Ketloy, C.; Palaga, T. Immune responses in COVID-19 and potential vaccines: Lessons learned from SARS and MERS epidemic. Asian Pac. J. Allergy Immunol 2020, 38, 1-9.

28. Bourgonje, A.R.; Abdulle, A.E.; Timens, W.; Hillebrands, J.L.; Navis, G.J.; Gordijn, S.J. Angiotensin-converting enzyme-2 (ACE2), SARS-CoV-2 and pathophysiology of coronavirus disease 2019 (COVID-19). J. Pathol. 2020. [CrossRef]

29. Spiegel, M.; Weber, F. Inhibition of cytokine gene expression and induction of chemokine genes in non-lymphatic cells infected with SARS coronavirus. Virol. J. 2006, 3, 17. [CrossRef]

30. Cristina, S.; Concetta, R.; Francesco, R.; Annalisa, C. SARS-Cov-2 infection: Response of human immune system and possible implications for the rapid test and treatment. Int. Immunopharmacol. 2020, 84, 106519.

31. Merad, M.; Martin, J.C. Author Correction: Pathological inflammation in patients with COVID-19: A key role for monocytes and macrophages. Nat. Rev. Immunol. 2020, 2020, 335-362. [CrossRef]

32. Pedersen, S.F.; Ho, Y.-C. SARS-CoV-2: A storm is raging. J. Clin. Investig. 2020, 130, 2202-2205. [CrossRef]

33. Giamarellos-Bourboulis, E.; Netea, M.G.; Rovina, N.; Akinosoglou, K.; Antoniadou, A.; Antonakos, N.; Damoraki, G.; Gkavogianni, T.; Adami, M.-E.; Katsaounou, P.; et al. Complex Immune Dysregulation in COVID-19 Patients with Severe Respiratory Failure. Cell Host Microbe 2020, 27, 992-1000. [CrossRef] 
34. Liu, Y.; Du, X.; Chen, J.; Jin, Y.; Peng, L.; Wang, H.H.; Luo, M.; Chen, L.; Zhao, Y. Neutrophil-to-lymphocyte ratio as an independent risk factor for mortality in hospitalized patients with COVID-19. J. Infect. 2020, 81, e6-e12. [CrossRef] [PubMed]

35. Sallard, E.; Lescure, F.-X.; Yazdanpanah, Y.; Mentre, F.; Peiffer-Smadja, N.; Ader, F.; Bouadma, L.; Poissy, J.; Timsit, J.-F.; Lina, B.; et al. Type 1 interferons as a potential treatment against COVID-19. Antivir. Res. 2020, 178, 104791. [CrossRef] [PubMed]

36. Blanco-Melo, D.; Nilsson-Payant, B.E.; Liu, W.-C.; Uhl, S.; Hoagland, D.; Møller, R.; Jordan, T.X.; Oishi, K.; Panis, M.; Sachs, D.; et al. Imbalanced Host Response to SARS-CoV-2 Drives Development of COVID-19. Cell 2020, 181, 1036-1045.e9. [CrossRef] [PubMed]

37. Mercer, J.; Greber, U.F. Virus interactions with endocytic pathways in macrophages and dendritic cells. Trends Microbiol. 2013, 21, 380-388. [CrossRef]

38. Conti, P.; Ronconi, G.; Caraffa, A.; Gallenga, C.; Ross, R.; Frydas, I.; Kritas, S. Induction of pro-inflammatory cytokines (IL-1 and IL-6) and lung inflammation by Coronavirus-19 (COVI-19 or SARS-CoV-2): Anti-inflammatory strategies. J. Biol. Regul. Homeost. Agents. 2020, 34, 1.

39. Moresco, E.M.Y.; LaVine, D.; Beutler, B. Toll-like receptors. Curr. Boil. 2011, 21, R488-R493. [CrossRef]

40. Prasad, A. Local Immunity Concept in the Context of the Novel Corona Viral Infection: A Consideration. Asian J. Immunol. 2020, 3, 16-25.

41. Ratajczak, M.Z.; Kucia, M. SARS-CoV-2 infection and overactivation of Nlrp3 inflammasome as a trigger of cytokine "storm" and risk factor for damage of hematopoietic stem cells. Leukemia 2020, 34, 1726-1729. [CrossRef]

42. Li, G.; Fan, Y.; Lai, Y.; Han, T.; Li, Z.; Zhou, P.; Pan, P.; Wang, W.; Hu, D.; Liu, X.; et al. Coronavirus infections and immune responses. J. Med. Virol. 2020, 92, 424-432. [CrossRef]

43. Ortega, J.T.; Serrano, M.L.; Pujol, F.H.; Rangel, H.R. Role of changes in SARS-CoV-2 spike protein in the interaction with the human ACE2 receptor: An in silico analysis. EXCLI J. 2020, 19, 410-417.

44. Ishii, K.; Hasegawa, H.; Nagata, N.; Mizutani, T.; Morikawa, S.; Suzuki, T.; Taguchi, F.; Tashiro, M.; Takemori, T.; Miyamura, T.; et al. Induction of protective immunity against severe acute respiratory syndrome coronavirus (SARS-CoV) infection using highly attenuated recombinant vaccinia virus DIs. Virology 2006, 351, 368-380. [CrossRef] [PubMed]

45. Bhattacharya, M.; Sharma, A.R.; Patra, P.; Ghosh, P.; Sharma, G.; Patra, B.C.; Lee, S.-S.; Chakraborty, C. Development of epitope-based peptide vaccine against novel coronavirus 2019 (SARS-COV-2): Immunoinformatics approach. J. Med. Virol. 2020, 92, 618-631. [CrossRef] [PubMed]

46. Frieman, M.B.; Chen, J.; Morrison, T.E.; Whitmore, A.; Funkhouser, W.; Ward, J.M.; Lamirande, E.W.; Roberts, A.; Heise, M.; Subbarao, K.; et al. SARS-CoV Pathogenesis Is Regulated by a STAT1 Dependent but a Type I, II and III Interferon Receptor Independent Mechanism. PLoS Pathog. 2010, 6, e1000849. [CrossRef] [PubMed]

47. Grifoni, A.; Sidney, J.; Zhang, Y.; Scheuermann, R.H.; Peters, B.; Sette, A. A Sequence Homology and Bioinformatic Approach Can Predict Candidate Targets for Immune Responses to SARS-CoV-2. Cell Host Microbe 2020, 27, 671-680. [CrossRef]

48. Rokni, M.; Ghasemi, V.; Tavakoli, Z. Immune responses and pathogenesis of SARS-CoV -2 during an outbreak in Iran: Comparison with SARS and MERS. Rev. Med. Virol. 2020, 30. [CrossRef]

49. Kumar, S.; Nyodu, R.; Maurya, V.K.; Saxena, S.K.; Saxena, S.K. Host Immune Response and Immunobiology of Human SARS-CoV-2 Infection. In Coronavirus Disease 2019 (COVID-19); Springer Science and Business Media LLC: Berlin/Heidelberg, Germany, 2020; pp. 43-53.

50. Netea, M.G.; Giamarellos-Bourboulis, E.J.; Domínguez-Andrés, J.; Curtis, N.; Van Crevel, R.; Van De Veerdonk, F.L.; Bonten, M. Trained Immunity: A Tool for Reducing Susceptibility to and the Severity of SARS-CoV-2 Infection. Cell 2020, 181, 969-977. [CrossRef]

51. Ganji, A.; Farahani, I.; Khansarinejad, B.; Ghazavi, A.; Mosayebi, G. Increased expression of CD8 marker on T-cells in COVID-19 patients. Blood Cell. Mol. Dis 2020, 102437. [CrossRef]

52. Cai, X. An Insight of Comparison between COVID-19 (2019-nCoV Disease) and SARS in Pathology and Pathogenesis. 2020. Available online: https://osf.io/hw34x/ (accessed on 3 August 2020).

53. Subbarao, K.; Mahanty, S. Respiratory Virus Infections: Understanding COVID-19. Immunity 2020, 52, 905-909. [CrossRef] 
54. Yuki, K.; Fujiogi, M.; Koutsogiannaki, S. COVID-19 pathophysiology: A review. Clin. Immunol. 2020, 215, 108427. [CrossRef]

55. Hussman, J.P. Cellular and molecular pathways of COVID-19 and potential points of therapeutic intervention. Front. Pharmacol. 2020. [CrossRef]

56. Lin, L.; Lu, L.; Cao, W.; Li, T. Hypothesis for potential pathogenesis of SARS-CoV-2 infection-a review of immune changes in patients with viral pneumonia. Emerg. Microbes Infect. 2020, 9, 727-732. [CrossRef] [PubMed]

57. Cafarotti, S. Severe Acute Respiratory Syndrome-Coronavirus-2 Infection and Patients with Lung Cancer: The Potential Role of Interleukin-17 Target Therapy. J. Thorac. Oncol. 2020, 15, e101-e103. [CrossRef] [PubMed]

58. $\quad$ Liang, Y.; Wang, M.-L.; Chien, C.-S.; Yarmishyn, A.A.; Yang, Y.-P.; Lai, W.-Y.; Luo, Y.-H.; Lin, Y.-T.; Chen, Y.-J.; Chang, P.-C.; et al. Highlight of Immune Pathogenic Response and Hematopathologic Effect in SARS-CoV, MERS-CoV, and SARS-Cov-2 Infection. Front. Immunol. 2020, 11. [CrossRef] [PubMed]

59. Lega, S.; Naviglio, S.; Volpi, S.; Tommasini, A. Recent Insight into SARS-CoV2 Immunopathology and Rationale for Potential Treatment and Preventive Strategies in COVID-19. Vaccines 2020, 8, 224. [CrossRef] [PubMed]

60. Xu, J.; Jia, W.; Wang, P.; Zhang, S.; Shi, X.; Wang, X.; Zhang, L.-Q.; Wang, T.; Golding, H.; Khurana, S. Antibodies and vaccines against Middle East respiratory syndrome coronavirus. Emerg. Microbes Infect. 2019, 8, 841-856. [CrossRef] [PubMed]

61. Ravichandran, S.; Coyle, E.M.; Klenow, L.; Tang, J.; Grubbs, G.; Liu, S.; Wang, T.; Golding, H.; Khurana, S. Antibody signature induced by SARS-CoV-2 spike protein immunogens in rabbits. Sci. Trans. Med. 2020, 12, 550-eabc3539. [CrossRef] [PubMed]

62. Premkumar, L.; Segovia-Chumbez, B.; Jadi, R.; Martinez, D.R.; Raut, R.; Markmann, A.J.; Cornaby, C.; Bartelt, L.; Weiss, S.; Park, Y.; et al. The receptor binding domain of the viral spike protein is an immunodominant and highly specific target of antibodies in SARS-CoV-2 patients. Sci. Immunol. 2020, 5, eabc8413. [CrossRef]

63. Yuan, M.; Wu, N.C.; Zhu, X.; Lee, C.-C.D.; So, R.T.Y.; Lv, H.; Mok, C.K.; Wilson, I.A. A highly conserved cryptic epitope in the receptor binding domains of SARS-CoV-2 and SARS-CoV. Science 2020, 368, 630-633. [CrossRef]

64. Zost, S.J.; Gilchuk, P.; Case, J.B.; Binshtein, E.; Chen, R.E.; Nkolola, J.P.; Schäfer, A.; Reidy, J.X.; Trivette, A.; Nargi, R.S.; et al. Potently neutralizing and protective human antibodies against SARS-CoV-2. Nature 2020, 2020, 1-10. [CrossRef]

65. Liu, L.; Wang, P.; Nair, M.S.; Yu, J.; Rapp, M.; Wang, Q.; Luo, Y.; Chan, J.F.-W.; Sahi, V.; Figueroa, A.; et al. Potent neutralizing antibodies directed to multiple epitopes on SARS-CoV-2 spike. Nature 2020, 1-10. [CrossRef]

66. Wilk, C.M. Coronaviruses hijack the complement system. Nat. Rev. Immunol. 2020, 20, 350. [CrossRef] [PubMed]

67. Willyard, C. Coronavirus blood-clot mystery intensifies. Nature 2020, 581, 250. [CrossRef] [PubMed]

68. Thachil, J.; Srivastava, A. SARS-2 Coronavirus-Associated Hemostatic Lung Abnormality in COVID-19: Is It Pulmonary Thrombosis or Pulmonary Embolism? Semin. Thromb. Hemost. 2020. [CrossRef] [PubMed]

69. Shimabukuro-Vornhagen, A.; Gödel, P.; Subklewe, M.; Stemmler, H.J.; Schlößer, H.A.; Schlaak, M.; Kochanek, M.; Böll, B.; Von Bergwelt-Baildon, M.S. Cytokine release syndrome. J. Immunother. Cancer 2018, 6, 56. [CrossRef]

70. Mehta, P.; McAuley, D.F.; Brown, M.; Sanchez, E.; Tattersall, R.S.; Manson, J.J. HLH Across Speciality Collaboration, UK COVID-19: Consider cytokine storm syndromes and immunosuppression. Lancet 2020, 395, 1033-1034. [CrossRef]

71. Zhang, C.; Wu, Z.; Li, J.W.; Zhao, H.; Wang, G.Q. The cytokine release syndrome (CRS) of severe COVID-19 and Interleukin-6 receptor (IL-6R) antagonist Tocilizumab may be the key to reduce the mortality. Int J. Antimicrob. Agents. 2020, 105954. [CrossRef]

72. Fehr, A.R.; Channappanavar, R.; Perlman, S. Middle East respiratory syndrome: Emergence of a pathogenic human coronavirus. Annu. Rev. Med. 2017, 68, 387-399. [CrossRef]

73. Aziz, M.; Fatima, R.; Assaly, R. Elevated interleukin-6 and severe COVID-19: A meta-analysis. J. Med. Virol. 2020. [CrossRef]

74. Moore, B.J.B.; June, C.H. Cytokine release syndrome in severe COVID-19. Science 2020, 368, 473-474. [CrossRef]

75. Scheller, J.; Rose-John, S. Interleukin-6 and its receptor: From bench to bedside. Med. Microbiol. Immunol. 2006, 195, 173-183. [CrossRef] 
76. Tanaka, T.; Narazaki, M.; Kishimoto, T. Immunotherapeutic implications of IL-6 blockade for cytokine storm. Immunotherapy 2016, 8, 959-970. [CrossRef] [PubMed]

77. Bekes, I.; Wulff, C. Controlling Vascular Permeability: How Does It Work and What Is the Impact on Normal and Pathological Angiogenesis. Tumor Angiogenesis A Key Target. Cancer Ther. 2019, 121-132.

78. Ross, S.H.; Cantrell, A.D. Signaling and Function of Interleukin-2 in T Lymphocytes. Annu. Rev. Immunol. 2018, 36, 411-433. [CrossRef] [PubMed]

79. Jones, E.; Maerz, B.; Buckner, M.D.J.H. IL-6: A cytokine at the crossroads of autoimmunity. Curr. Opin. Immunol. 2018, 55, 9-14. [CrossRef]

80. Xu, X.; Han, M.; Li, T.; Sun, W.; Wang, D.; Fu, B.; Zhou, Y.; Zheng, X.; Yang, Y.; Li, X.; et al. Effective treatment of severe COVID-19 patients with tocilizumab. Proc. Natl. Acad. Sci. USA 2020, 117, 10970-10975. [CrossRef]

81. Navarro, G.; Taroumian, S.; Barroso, N.; Duan, L.; Furst, D.E. Tocilizumab in rheumatoid arthritis: A meta-analysis of efficacy and selected clinical conundrums. Semin. Arthritis Rheum. 2014, 43, 458-469. [CrossRef]

82. Yokota, S.; Miyamae, T.; Imagawa, T.; Iwata, N.; Katakura, S.; Mori, M.; Woo, P.; Nishimoto, N.; Yoshizaki, K.; Kishimoto, T. Therapeutic efficacy of humanized recombinant anti-interleukin-6 receptor antibody in children with systemic-onset juvenile idiopathic arthritis. Arthritis Rheum. 2005, 52, 818-825. [CrossRef]

83. Khiali, S.; Khani, E.; Entezari-Maleki, T. A Comprehensive Review on Tocilizumab in COVID-19 Acute Respiratory Distress Syndrome. J. Clin. Pharmacol. 2020. [CrossRef]

84. Huang, C.; Wang, Y.; Li, X.; Ren, L.; Zhao, J.; Hu, Y. Clinical features of patients infected with 2019 novel coronavirus in Wuhan, China. Lancet 2020, 395, 497-506. [CrossRef]

85. Gong, J.; Dong, H.; Xia, S.Q.; Huang, Y.Z.; Wang, D.; Zhao, Y.; Liu, W.; Tu, S.; Zhang, M.; Wang, Q.; et al. Correlation Analysis Between Disease Severity and Inflammation-related Parameters in Patients with COVID-19 Pneumonia. MedRxiv 2020. [CrossRef]

86. Feldmann, M.; Maini, R.N.; Woody, J.N.; Holgate, S.T.; Winter, G.; Rowland, M.; Richards, D.; Hussell, T. Trials of anti-tumour necrosis factor therapy for COVID-19 are urgently needed. Lancet 2020, 395, 1407-1409. [CrossRef]

87. The Centers for Disease Control and Prevention, Older Adults. Available online: https://www.cdc.gov/ coronavirus/2019-ncov/need-extra-precautions/older-adults.html (accessed on 30 July 2020).

88. Booth, C.M.; Matukas, L.M.; Tomlinson, G.; Rachlis, A.R.; Rose, D.B.; Dwosh, H.A.; Walmsley, S.L.; Mazzulli, T.; Avendano, M.; Derkach, P.; et al. Clinical Features and Short-term Outcomes of 144 Patients With SARS in the Greater Toronto Area. JAMA 2003, 289, 2801. [CrossRef] [PubMed]

89. Alqahtani, F.Y.; Aleanizy, F.; Mohamed, R.A.E.H.; Alanazi, M.S.; Mohamed, N.; Alrasheed, M.M.; Abanmy, N.; Alhawassi, T. Prevalence of comorbidities in cases of Middle East respiratory syndrome coronavirus: A retrospective study. Epidemiol. Infect. 2018, 147, 1-5. [CrossRef] [PubMed]

90. The Centers for Disease Control and Prevention, People with Certain Medical Conditions. Available online: https: //www.cdc.gov/coronavirus/2019-ncov/need-extra-precautions/people-with-medical-conditions.html (accessed on 17 July 2020).

91. Sanyaolu, O.; Okorie, C.; Marinkovic, A.; Patidar, R.; Younis, K.; Desai, P.; Hosein, Z.; Padda, I.; Mangat, J.; Altaf, M. Comorbidity and its Impact on Patients with COVID-19. SN Compr. Clin. Med. 2020, 2020, 1-8. [CrossRef]

92. Yang, J.; Zheng, Y.; Gou, X.; Pu, K.; Chen, Z.; Guo, Q.; Ji, R.; Wang, H.; Wang, Y.; Zhou, Y. Prevalence of comorbidities and its effects in patients infected with SARS-CoV-2: A systematic review and meta-analysis. Int. J. Infect. Dis. 2020, 94, 91-95. [CrossRef] [PubMed]

93. Bajgain, K.T.; Badal, S.; Bajgain, B.B.; Santana, M.J. Prevalence of Comorbidities Among Individuals With COVID-19: A Rapid Review of current Literature. Am. J. Infect. Control. 2020. [CrossRef]

94. Paudel, S.S. A Meta-Analysis of 2019 Novel Corona Virus Patient Clinical Characteristics and Comorbidities. 2020. Available online: https://www.researchsquare.com/article/rs-21831/v1 (accessed on 3 August 2020).

95. Guan, W.-J.; Liang, W.-H.; Zhao, Y.; Liang, H.-R.; Chen, Z.-S.; Li, Y.-M.; Liu, X.-Q.; Chen, R.-C.; Tang, C.-L.; Wang, T.; et al. Comorbidity and its impact on 1590 patients with COVID-19 in China: A nationwide analysis. Eur. Respir. J. 2020, 55, 2000547. [CrossRef]

96. Gold, M.S.; Sehayek, D.; Gabrielli, S.; Zhang, X.; McCusker, C.; Ben-Shoshan, M. COVID-19 and comorbidities: A systematic review and meta-analysis. Postgrad. Med. 2020, 1-7. [CrossRef] 
97. Noor, F.M.; Islam, M. Prevalence of Clinical Manifestations and Comorbidities of Coronavirus (COVID-19) Infection: A Meta-Analysis. Fortune J. Health Sci. 2020, 1, 55-97. [CrossRef]

98. Richardson, S.; Hirsch, J.S.; Narasimhan, M.; Crawford, J.M.; McGinn, T.; Davidson, K.W.; Barnaby, D.P.; Becker, L.B.; Chelico, J.D.; Cohen, S.L.; et al. Presenting Characteristics, Comorbidities, and Outcomes Among 5700 Patients Hospitalized With COVID-19 in the New York City Area. JAMA 2020, 323, 2052. [CrossRef]

99. Brown, A.J.; Won, J.J.; Graham, R.L.; Dinnon, K.H.; Sims, A.C.; Feng, J.Y.; Cihlar, T.; Denison, M.R.; Baric, R.S.; Sheahan, T.P. Broad spectrum antiviral remdesivir inhibits human endemic and zoonotic deltacoronaviruses with a highly divergent RNA dependent RNA polymerase. Antivir. Res. 2019, 169, 104541. [CrossRef] [PubMed]

100. Sheahan, T.P.; Sims, A.C.; Graham, R.L.; Menachery, V.D.E.; Gralinski, L.; Case, J.B.; Leist, S.R.; Pyrc, K.; Feng, J.Y.; Trantcheva, I.; et al. Broad-spectrum antiviral GS-5734 inhibits both epidemic and zoonotic coronaviruses. Sci. Transl. Med. 2017, 9, eaal3653. [CrossRef] [PubMed]

101. Wang, M.; Cao, R.; Zhang, L.; Yang, X.; Liu, J.; Xu, M.; Shi, Z.; Hú, Z.; Zhong, W.; Xiao, G. Remdesivir and chloroquine effectively inhibit the recently emerged novel coronavirus (2019-nCoV) in vitro. Cell Res. 2020, 30, 269-271. [CrossRef] [PubMed]

102. Holshue, M.L.; DeBolt, C.; Lindquist, S.; Lofy, K.H.; Wiesman, J.; Bruce, H.; Spitters, C.; Ericson, K.; Wilkerson, S.; Tural, A.; et al. First Case of 2019 Novel Coronavirus in the United States. N. Engl. J. Med. 2020, 382, 929-936. [CrossRef]

103. McCreary, E.K.; Pogue, J.M. COVID-19 Treatment: A Review of Early and Emerging Options. Open Forum Infect. Dis. 2020, 7. [CrossRef]

104. Zhang, B.; Liu, S.; Tan, T.; Huang, W.; Dong, Y.; Chen, L. Treatment with convalescent plasma for critically ill patients with SARS-CoV-2 infection. Chest 2020, 158. [CrossRef]

105. Grein, J.; Ohmagari, N.; Shin, D.; Diaz, G.; Asperges, E.; Castagna, A.; Feldt, T.; Green, G.; Green, M.L.; Lescure, F.-X.; et al. Compassionate Use of Remdesivir for Patients with Severe Covid-19. N. Engl. J. Med. 2020, 382, 2327-2336. [CrossRef]

106. Wang, Y.; Zhang, D.; Du, G.; Du, R.; Zhao, J.; Jin, Y.; Fu, S.; Gao, L.; Cheng, Z.; Lu, Q.; et al. Remdesivir in adults with severe COVID-19: A randomised, double-blind, placebo-controlled, multicentre trial. Lancet 2020, 395, 1569-1578. [CrossRef]

107. Chu, C.; Cheng, V.C.C.; Hung, I.F.N.; Wong, M.M.L.; Chan, K.; Kao, R.Y.T.; Poon, L.L.; Wong, C.L.P.; Guan, Y.; Peiris, J.S.M.; et al. Role of lopinavir/ritonavir in the treatment of SARS: Initial virological and clinical findings. Thorax 2004, 59, 252-256. [CrossRef]

108. Wu, C.; Liu, Y.; Yang, Y.; Zhang, P.; Zhong, W.; Wang, Y.; Wang, Q.; Xu, Y.; Li, M.; Li, X.; et al. Analysis of therapeutic targets for SARS-CoV-2 and discovery of potential drugs by computational methods. Acta Pharm. Sin. B 2020, 10, 766-788. [CrossRef]

109. Liu, C.; Zhou, Q.; Li, Y.; Garner, L.V.; Watkins, S.P.; Carter, L.J.; Smoot, J.; Gregg, A.C.; Daniels, A.D.; Jervey, S.; et al. Research and Development on Therapeutic Agents and Vaccines for COVID-19 and Related Human Coronavirus Diseases. ACS Cent. Sci. 2020, 6, 315-331. [CrossRef] [PubMed]

110. Lim, J.; Jeon, S.; Shin, H.Y.; Kim, M.J.; Seong, Y.M.; Lee, W.J.; Choe, K.-W.; Kang, Y.M.; Lee, B.; Park, S.-J.; et al. Case of the index patient who caused tertiary transmission of coronavirus disease 2019 in Korea: The application of lopinavir/ritonavir for the treatment of COVID-19 pneumonia monitored by quantitative RT-PCR. J. Korean Med. Sci. 2020, 35, e79. [CrossRef] [PubMed]

111. Wang, Z.; Chen, X.; Lu, Y.; Chen, F.; Zhang, W. Clinical characteristics and therapeutic procedure for four cases with 2019 novel coronavirus pneumonia receiving combined Chinese and Western medicine treatment. Biosci. Trends 2020, 14, 64-68. [CrossRef] [PubMed]

112. Young, B.E.; Ong, S.W.X.; Kalimuddin, S.; Low, J.G.; Tan, S.Y.; Loh, J.; Ng, O.-T.; Marimuthu, K.; Ang, L.W.; Mak, T.M.; et al. Epidemiologic Features and Clinical Course of Patients Infected With SARS-CoV-2 in Singapore. JAMA 2020. [CrossRef] [PubMed]

113. Zhou, F.; Yu, T.; Du, R.; Fan, G.; Liu, Y.; Liu, Z.; Xiang, J.; Wang, Y.; Song, B.; Gu, X.; et al. Clinical course and risk factors for mortality of adult inpatients with COVID-19 in Wuhan, China: A retrospective cohort study. Lancet 2020, 395, 1054-1062. [CrossRef] [PubMed] 
114. Cao, B.; Wang, Y.; Wen, D.; Liu, W.; Wang, J.; Fan, G.; Ruan, L.; Song, B.; Cai, Y.; Wei, M.; et al. A Trial of Lopinavir-Ritonavir in Adults Hospitalized with Severe Covid-19. N. Engl. J. Med. 2020, 382, 1787-1799. [CrossRef]

115. Baden, L.R.; Rubin, E.J. Covid-19-The Search for Effective Therapy. N. Engl. J. Med. 2020, 382, 1851-1852. [CrossRef]

116. Crotti, L.; Arbelo, E. COVID-19 treatments, QT interval, and arrhythmic risk: The need for an international registry on arrhythmias. Hear. Rhythm. 2020. [CrossRef]

117. Rhodes, A.; Evans, L.; Alhazzani, W.; Levy, M.M.; Antonelli, M.; Ferrer, R.; Kumar, A.; Sevransky, J.E.; Sprung, C.L.; Nunnally, M.E.; et al. Surviving Sepsis Campaign. Crit. Care Med. 2017, 45, 486-552. [CrossRef]

118. Furuta, Y.; Komeno, T.; Nakamura, T. Favipiravir (T-705), a broad spectrum inhibitor of viral RNA polymerase. Proc. Jpn. Acad. Ser. B 2017, 93, 449-463. [CrossRef]

119. Delang, L.; Abdelnabi, R.; Neyts, J. Favipiravir as a potential countermeasure against neglected and emerging RNA viruses. Antivir. Res. 2018, 153, 85-94. [CrossRef] [PubMed]

120. Cai, Q.; Yang, M.; Liu, D.; Chen, J.; Shu, D.; Xia, J.; Liao, X.; Gu, Y.; Cai, Q.; Yang, Y.; et al. Experimental Treatment with Favipiravir for COVID-19: An Open-Label Control Study. Engineering 2020. [CrossRef] [PubMed]

121. Tu, Y.-F.; Chien, C.-S.; Yarmishyn, A.A.; Lin, Y.-Y.; Luo, Y.-H.; Lai, W.-Y.; Yang, D.-M.; Chou, S.-J.; Yang, Y.-P.; Wang, M.-L.; et al. A Review of SARS-CoV-2 and the Ongoing Clinical Trials. Int. J. Mol. Sci. 2020, 21, 2657. [CrossRef] [PubMed]

122. Chang, C.; Huang, J.; Yin, P.; Zhang, Y.; Cheng, Z.; Wu, J.; Chen, S.; Zhang, Y.; Chen, B.; Lu, M.; et al. Favipiravir versus Arbidol for COVID-19: A Randomized Clinical Trial. medRxiv 2020. [CrossRef]

123. Rosa, S.G.V.; Santos, W.C. Clinical trials on drug repositioning for COVID-19 treatment. Rev. Panam. Salud Pública 2020, 44, e40-e13. [CrossRef]

124. Gordon, C.J.; Tchesnokov, E.P.; Woolner, E.; Perry, J.K.; Feng, J.Y.; Porter, D.P.; Götte, M. Remdesivir is a direct-acting antiviral that inhibits RNA-dependent RNA polymerase from severe acute respiratory syndrome coronavirus 2 with high potency. J. Boil. Chem. 2020, 295, 6785-6797. [CrossRef]

125. Sidwell, R.W.; Huffman, J.H.; Khare, G.P.; Allen, L.B.J.T.; Witkowski, R.; Robins, K. Broad-spectrum antiviral activity of virazole: 1-f8-D-ribofuranosyl-1, 2, 4-triazole-3-carboxamide. Science 1972, 177, 705-706. [CrossRef]

126. Thomas, E.; Ghany, M.G.; Liang, T.J. The application and mechanism of action of ribavirin in therapy of hepatitis C. Antivir. Chem. Chemother. 2012, 23, 1-12. [CrossRef]

127. Graci, J.D.; Cameron, C.E. Mechanisms of action of ribavirin against distinct viruses. Rev. Med. Virol. 2005, 16, 37-48. [CrossRef]

128. Morgenstern, B.; Michaelis, M.; Baer, P.C.; Doerr, H.W.; Cinatl, J.; Cinatl, J. Ribavirin and interferon- $\beta$ synergistically inhibit SARS-associated coronavirus replication in animal and human cell lines. Biochem. Biophys. Res. Commun. 2005, 326, 905-908. [CrossRef]

129. Falzarano, D.; De Wit, E.; Martellaro, C.; Callison, J.; Munster, V.J.; Feldmann, H. Inhibition of novel $\beta$ coronavirus replication by a combination of interferon- $\alpha 2 b$ and ribavirin. Sci. Rep. 2013, 3, srep01686. [CrossRef] [PubMed]

130. Knowles, S.R.; Phillips, E.J.; Dresser, L.; Matukas, L. Common Adverse Events Associated with the Use of Ribavirin for Severe Acute Respiratory Syndrome in Canada. Clin. Infect. Dis. 2003, 37, 1139-1142. [CrossRef] [PubMed]

131. Altınbas, S.; Holmes, J.A.; Altınbas, A. Hepatitis C Virus Infection in Pregnancy. Gastroenterol. Nurs. 2020, 43, 12-21. [CrossRef] [PubMed]

132. Zhang, Q.; Wang, Y.; Qi, C.; Shen, L.; Li, J. Clinical trial analysis of 2019-nCoV therapy registered in China. J. Med. Virol. 2020, 92, 540-545. [CrossRef] [PubMed]

133. Boriskin, Y.; Leneva, I.; Pecheur, E.-I.; Polyák, S. Arbidol: A Broad-Spectrum Antiviral Compound that Blocks Viral Fusion. Curr. Med. Chem. 2008, 15, 997-1005. [CrossRef]

134. Blaising, J.; Polyak, S.J.; Pécheur, E.-I. Arbidol as a broad-spectrum antiviral: An update. Antivir. Res. 2014, 107, 84-94. [CrossRef]

135. Kadam, R.U.; Wilson, I.A. Structural basis of influenza virus fusion inhibition by the antiviral drug Arbidol. Proc. Natl. Acad. Sci. USA 2016, 114, 206-214. [CrossRef] 
136. Khamitov, A.; Loginova, R.; Shchukina, S.I.; Borisevich, V.N.S.V.; Maksimov, V.A.; Shuster, A.M. Antiviral activity of arbidol and its derivatives against the pathogen of severe acute respiratory syndrome in the cell cultures. Vopr. Virusol. 2008, 53, 9-13.

137. Wang, Z.; Yang, B.; Li, Q.; Wen, L.; Zhang, R. Clinical Features of 69 Cases With Coronavirus Disease 2019 in Wuhan, China. Clin. Infect. Dis. 2020. [CrossRef]

138. McKee, D.L.; Sternberg, A.; Stange, U.; Laufer, S.; Naujokat, C. Candidate drugs against SARS-CoV-2 and COVID-19. Pharmacol. Res. 2020, 157, 104859. [CrossRef]

139. Bertram, S.; Heurich, A.; Lavender, H.; Gierer, S.; Danisch, S.; Perin, P.; Lucas, J.M.; Nelson, P.S.; Pöhlmann, S.; Soilleux, E. Influenza and SARS-Coronavirus Activating Proteases TMPRSS2 and HAT Are Expressed at Multiple Sites in Human Respiratory and Gastrointestinal Tracts. PLoS ONE 2012, 7, e35876. [CrossRef] [PubMed]

140. Matsuyama, S.; Nagata, N.; Shirato, K.; Kawase, M.; Takeda, M.; Taguchi, F. Efficient Activation of the Severe Acute Respiratory Syndrome Coronavirus Spike Protein by the Transmembrane Protease TMPRSS2. J. Virol. 2010, 84, 12658-12664. [CrossRef] [PubMed]

141. Zhou, Y.; Vedantham, P.; Lu, K.; Agudelo, J.; Carrion, R.; Nunneley, J.W.; Barnard, D.; Pöhlmann, S.; McKerrow, J.H.; Renslo, A.R.; et al. Protease inhibitors targeting coronavirus and filovirus entry. Antivir. Res. 2015, 116, 76-84. [CrossRef] [PubMed]

142. Kawase, M.; Shirato, K.; Van Der Hoek, L.; Taguchi, F.; Matsuyama, S. Simultaneous Treatment of Human Bronchial Epithelial Cells with Serine and Cysteine Protease Inhibitors Prevents Severe Acute Respiratory Syndrome Coronavirus Entry. J. Virol. 2012, 86, 6537-6545. [CrossRef]

143. Hoffmann, M.; Kleine-Weber, H.; Schroeder, S.; Krüger, N.; Herrler, T.; Erichsen, S.; Schiergens, T.S.; Herrler, G.; Wu, N.-H.; Nitsche, A.; et al. SARS-CoV-2 Cell Entry Depends on ACE2 and TMPRSS2 and Is Blocked by a Clinically Proven Protease Inhibitor. Cell 2020, 181, 271-280. [CrossRef] [PubMed]

144. Iwaki, M.; Ino, Y.; Motoyoshi, A.; Ozeki, M.; Sato, T.; Kurumi, M.; Aoyama, T. Pharmacological studies of FUT-175, nafamostat mesilate. V. Effects on the pancreatic enzymes and experimental acute pancreatitis in rats. Jpn. J. Pharmacol. 1986, 41, 155-162. [CrossRef]

145. Chen, X.; Xu, Z.; Zeng, S.; Wang, X.; Liu, W.; Qian, L.; Wei, J.; Yang, X.; Shen, Q.; Gong, Z.; et al. The Molecular Aspect of Antitumor Effects of Protease Inhibitor Nafamostat Mesylate and Its Role in Potential Clinical Applications. Front. Oncol. 2019, 9, 852. [CrossRef]

146. Hoffmann, M.; Schroeder, S.; Kleine-Weber, H.; Müller, M.A.; Drosten, C.; Pöhlmann, S. Nafamostat Mesylate Blocks Activation of SARS-CoV-2: New Treatment Option for COVID-19. Antimicrob. Agents Chemother. 2020, 64. [CrossRef]

147. Devaux, C.A.; Rolain, J.-M.; Colson, P.; Raoult, D. New insights on the antiviral effects of chloroquine against coronavirus: What to expect for COVID-19? Int. J. Antimicrob. Agents 2020, 55, 105938. [CrossRef]

148. Vincent, M.J.; Bergeron, E.; Benjannet, S.; Erickson, B.R.; Rollin, P.E.; Ksiazek, T.G.; Seidah, N.G.; Nichol, S.T. Chloroquine is a potent inhibitor of SARS coronavirus infection and spread. Virol. J. 2005, 2, 69. [CrossRef]

149. Singh, A.K.; Singh, A.; Shaikh, A.; Singh, R.; Misra, A. Chloroquine and hydroxychloroquine in the treatment of COVID-19 with or without diabetes: A systematic search and a narrative review with a special reference to India and other developing countries. Diabetes Metab. Syndr. Clin. Res. Rev. 2020, 14, 241-246. [CrossRef] [PubMed]

150. Savarino, A.; Boelaert, J.R.; Cassone, A.; Majori, G.; Cauda, R. Effects of chloroquine on viral infections: An old drug against today's diseases. Lancet Infect. Dis. 2003, 3, 722-727. [CrossRef]

151. Colson, P.; Rolain, J.-M.; Lagier, J.-C.; Brouqui, P.; Raoult, D. Chloroquine and hydroxychloroquine as available weapons to fight COVID-19. Int. J. Antimicrob. Agents 2020, 55, 105932. [CrossRef] [PubMed]

152. Bernstein, H.N. Ocular safety of hydroxychloroquine. Ann. Ophthalmol. 1991, 23, 292-296.

153. Ratliff, N.B.; Estes, M.L.; Myles, J.L.; Shirey, E.K.; McMahon, J.T. Diagnosis of Chloroquine Cardiomyopathy by Endomyocardial Biopsy. N. Engl. J. Med. 1987, 316, 191-193. [CrossRef]

154. McChesney, E.W. Animal toxicity and pharmacokinetics of hydroxychloroquine sulfate. Am. J. Med. 1983, 75, 11-18. [CrossRef]

155. Al-Bari, M.A.A. Targeting endosomal acidification by chloroquine analogs as a promising strategy for the treatment of emerging viral diseases. Pharmacol. Res. Perspect. 2017, 5, e00293. [CrossRef] 
156. Biot, C.; Daher, W.; Chavain, N.; Fandeur, T.; Khalife, J.; Dive, D.; De Clercq, E. Design and Synthesis of Hydroxyferroquine Derivatives with Antimalarial and Antiviral Activities. J. Med. Chem. 2006, 49, 2845-2849. [CrossRef]

157. Yao, X.; Ye, F.; Zhang, M.; Cui, C.; Huang, B.; Niu, P.; Liu, X.; Zhao, L.; Dong, E.; Song, C.; et al. In Vitro Antiviral Activity and Projection of Optimized Dosing Design of Hydroxychloroquine for the Treatment of Severe Acute Respiratory Syndrome Coronavirus 2 (SARS-CoV-2). Clin. Infect. Dis. 2020. [CrossRef]

158. Gautret, P.; Lagier, J.-C.; Parola, P.; Hoang, V.T.; Meddeb, L.; Mailhe, M.; Doudier, B.; Courjon, J.; Giordanengo, V.; Vieira, V.E.; et al. Hydroxychloroquine and azithromycin as a treatment of COVID-19: Results of an open-label non-randomized clinical trial. Int. J. Antimicrob. Agents 2020, 2020, 105949. [CrossRef]

159. Ferner, R.E.; Aronson, J.K. Chloroquine and hydroxychloroquine in covid-19. BMJ 2020, 369, m1432. [CrossRef] [PubMed]

160. Liew, D.; Roberts, D.; Hill, C. Hydroxychloroquine for COVID-19: A Cautionary Tale. InSight+. Available online: https://insightplus.mja.com.au/2020/21/hydroxychloroquine-for-covid-19-a-cautionarytale/ (accessed on 1 June 2020).

161. Chorin, E.; Wadhwani, L.; Magnani, S.; Dai, M.; Shulman, E.; Nadeau-Routhier, C.; Knotts, R.; Bar-Cohen, R.; Kogan, E.; Barbhaiya, C.; et al. QT interval prolongation and torsade de pointes in patients with COVID-19 treated with hydroxychloroquine/azithromycin. Hear. Rhythm. 2020. [CrossRef] [PubMed]

162. Administration USFaD. Coronavirus (COVID-19) Update: FDA Warns of Newly Discovered Potential Drug Interaction That May Reduce Effectiveness of a COVID-19 Treatment Authorized for Emergency Use. Available online: https://www.fda.gov/news-events/press-announcements/coronavirus-covid-19-updatefda-warns-newly-discovered-potential-drug-interaction-may-reduce (accessed on 15 June 2020).

163. Administration FaD. FDA Cautions Against Use of Hydroxychloroquine or Chloroquine for COVID-19 Outside of the Hospital Setting or a Clinical Trial Due to Risk of Heart Rhythm Problems. 1 July 2020. Available online: https://www.fda.gov/drugs/drug-safety-and-availability/fda-cautions-againstuse-hydroxychloroquine-or-chloroquine-covid-19-outside-hospital-setting-or (accessed on 1 July 2020).

164. No Clinical Benefit from Use of Hydroxychloroquine in Hospitalised Patients with COVID-19. 5 June 2020. Available online: https://www.ox.ac.uk/news/2020-06-05-no-clinical-benefit-use-hydroxychloroquinehospitalised-patients-covid-19 (accessed on 5 June 2020).

165. Health. NIo. COVID-19 Treatment Guidelines Panel. Coronavirus Disease 2019 (COVID-19) Treatment Guidelines. 16 June 2020. Available online: https://www.covid19treatmentguidelines.nih.gov/ (accessed on 30 July 2020).

166. Caly, L.; Druce, J.D.; Catton, M.G.; Jans, D.A.; Wagstaff, K.M. The FDA-approved drug ivermectin inhibits the replication of SARS-CoV-2 in vitro. Antivir. Res. 2020, 178, 104787. [CrossRef]

167. Wagstaff, K.M.; Rawlinson, S.M.; Hearps, A.C.; Jans, D.A. An AlphaScreen(R)-Based Assay for High-Throughput Screening for Specific Inhibitors of Nuclear Import. J. Biomol. Screen. 2011, 16, 192-200. [CrossRef] [PubMed]

168. Yang, S.N.; Atkinson, S.C.; Wang, C.; Lee, A.; Bogoyevitch, M.A.; Borg, N.A.; Jans, D.A. The broad spectrum antiviral ivermectin targets the host nuclear transport importin $\alpha / \beta 1$ heterodimer. Antivir. Res. 2020, 177, 104760. [CrossRef] [PubMed]

169. Momekov, G.; Momekova, D. Ivermectin as a potential COVID-19 treatment from the pharmacokinetic point of view: Antiviral levels are not likely attainable with known dosing regimens. Biotechnol. Biotechnol. Equip. 2020, 34, 469-474. [CrossRef]

170. Beigel, J.H. Polyclonal and monoclonal antibodies for the treatment of influenza. Curr. Opin. Infect. Dis. 2018, 31, 527-534. [CrossRef]

171. Marano, G.; Vaglio, S.; Pupella, S.; Facco, G.; Catalano, L.; Liumbruno, G.M.; Grazzini, G. Convalescent plasma: New evidence for an old therapeutic tool? High Speed Blood Transfus. Equip. 2015, 14, 152-157.

172. Chaudhuri, S.; Symons, J.A.; Deval, J. Innovation and trends in the development and approval of antiviral medicines: 1987-2017 and beyond. Antivir. Res. 2018, 155, 76-88. [CrossRef]

173. Rosenke, K.E.; Bounds, C.; Hanley, P.W.; Saturday, G.; Sullivan, E.; Wu, H.; Jiao, J.-A.; Feldmann, H.; Schmaljohn, C.; Safronetz, D. Human Polyclonal Antibodies Produced by Transchromosomal Cattle Provide Partial Protection Against Lethal Zaire Ebolavirus Challenge in Rhesus Macaques. J. Infect. Dis. 2018, 218, S658-S661. [CrossRef] 
174. Zhang, J.-S.; Chen, J.-T.; Liu, Y.-X.; Zhang, Z.-S.; Gao, H.; Liu, Y.; Wang, X.; Ning, Y.; Liu, Y.-F.; Gao, Q.; et al. A serological survey on neutralizing antibody titer of SARS convalescent sera. J. Med. Virol. 2005, 77, 147-150. [CrossRef] [PubMed]

175. Van Griensven, J.; Edwards, T.; De Lamballerie, X.; Semple, M.G.; Gallian, P.; Baize, S.; Horby, P.; Raoul, H.; Magassouba, N.; Antierens, A.; et al. Evaluation of Convalescent Plasma for Ebola Virus Disease in Guinea. N. Engl. J. Med. 2016, 374, 33-42. [CrossRef]

176. Anudeep, T.; Jeyaraman, M.; Shetty, D.U.; Raj, H.; Ajay, S.; Rajeswari Somasundaram, V.K.V.; Kumar, V.; Jain, R.; Shirodkar, J. Convalescent Plasma as a plausible therapeutic option in nCOVID-19-A Review. J. Clin. Trials 2020, 10, 409. [CrossRef]

177. Casadevall, A.; Pirofski, L.-A. The convalescent sera option for containing COVID-19. J. Clin. Investig. 2020, 130, 1545-1548. [CrossRef] [PubMed]

178. Cheng, Y.; Wong, R.S.-M.; Soo, Y.O.Y.; Wong, W.S.; Lee, C.K.; Ng, M.H.L.; Chan, P.; Wong, K.C.; Leung, C.B.; Cheng, G. Use of convalescent plasma therapy in SARS patients in Hong Kong. Eur. J. Clin. Microbiol. Infect. Dis. 2004, 24, 44-46. [CrossRef] [PubMed]

179. Yeh, K.-M.; Chiueh, T.-S.; Siu, L.K.; Lin, J.-C.; Chan, P.K.; Peng, M.-Y.; Wan, H.-L.; Chen, J.-H.; Hu, B.-S.; Perng, C.-L.; et al. Experience of using convalescent plasma for severe acute respiratory syndrome among healthcare workers in a Taiwan hospital. J. Antimicrob. Chemother. 2005, 56, 919-922. [CrossRef]

180. Ko, J.-H.; Seok, H.; Cho, S.Y.; Ha, Y.E.; Baek, J.Y.; Kim, S.H.; Kim, Y.-J.; Park, J.K.; Chung, C.R.; Kang, E.-S.; et al. Challenges of convalescent plasma infusion therapy in Middle East respiratory coronavirus infection: A single centre experience. Antivir. Ther. 2018, 23, 617-622. [CrossRef]

181. Zhang, L.; Pang, R.; Xue, X.; Bao, J.; Ye, S.; Dai, Y.; Zheng, Y.; Fu, Q.; Hu, Z.; Yi, Y. Anti-SARS-CoV-2 virus antibody levels in convalescent plasma of six donors who have recovered from COVID-19. Aging 2020, 12, 6536-6542. [CrossRef]

182. The Efficacy of Intravenous Immunoglobulin Therapy for Severe 2019-nCoV Infected Pneumonia. Available online: https://clinicaltrials.gov/ct2/show/NCT04261426 (accessed on 3 August 2020).

183. Anti-SARS-CoV-2 Inactivated Convalescent Plasma in the Treatment of COVID-19. Available online: https://clinicaltrials.gov/ct2/show/NCT04292340 (accessed on 3 August 2020).

184. Treatment of Acute Severe 2019-nCoV Pneumonia with Immunoglobulin from Cured Patients. Available online: https://www.clinicaltrials.gov/ct2/show/NCT04264858 (accessed on 3 August 2020).

185. Efficacy and Safety Human Coronavirus Immune Plasma (HCIP) vs. Control (SARS-CoV-2 Non-Immune Plasma) Among Adults Exposed to COVID-19. Available online: https://clinicaltrials.gov/ct2/show/study/ NCT04323800 (accessed on 3 August 2020).

186. Convalescent Plasma for Patients with COVID-19. Available online: https://clinicaltrials.gov/ct2/show/ NCT04332380 (accessed on 3 August 2020).

187. Investigating Effect of Convalescent Plasma on COVID-19 Patients Outcome: A Clinical Trial. Available online: https://clinicaltrials.gov/ct2/show/NCT04327349 (accessed on 3 August 2020).

188. Study Testing Convalescent Plasma vs Best Supportive Care. Available online: https://clinicaltrials.gov/ct2/ show/NCT04333251 (accessed on 3 August 2020).

189. Safety in Convalescent Plasma Transfusion to COVID-19. Available online: https:/clinicaltrials.gov/ct2/ show/NCT04333355 (accessed on 3 August 2020).

190. Hartung, H.-P.; Mouthon, L.; Ahmed, R.; Jordan, S.; Laupland, K.B.; Jolles, S. Clinical applications of intravenous immunoglobulins (IVIg)—Beyond immunodeficiencies and neurology. Clin. Exp. Immunol. 2009, 158, 23-33. [CrossRef]

191. Kazatchkine, M.D.; Kaveri, S. Immunomodulation of Autoimmune and Inflammatory Diseases with Intravenous Immune Globulin. N. Engl. J. Med. 2001, 345, 747-755. [CrossRef]

192. Ferrara, G.; Zumla, A.; Maeurer, M. Intravenous Immunoglobulin (IVIg) for Refractory and Difficult-to-treat Infections. Am. J. Med. 2012, 125, 1036.e1-1036.e8. [CrossRef] [PubMed]

193. Stockman, L.J.; Bellamy, R.; Garner, P. SARS: Systematic Review of Treatment Effects. PLoS Med. 2006,3 , e343. [CrossRef] [PubMed]

194. Mustafa, S.; Balkhy, H.; Gabere, M.N. Current treatment options and the role of peptides as potential therapeutic components for Middle East Respiratory Syndrome (MERS): A review. J. Infect. Public Health 2018, 11, 9-17. [CrossRef] [PubMed] 
195. Chong, Y.P.; Song, J.Y.; Bin Seo, Y.; Choi, J.-P.; Shin, H.-S.; Team, R.R. Antiviral Treatment Guidelines for Middle East Respiratory Syndrome. Infect. Chemother. 2015, 47, 212-222. [CrossRef] [PubMed]

196. Shi, H.; Zhou, C.; He, P.; Huang, S.; Duan, Y.; Wang, X.; Lin, K.; Zhou, C.; Zhang, X.; Zha, Y. Successful treatment of plasma exchange followed by intravenous immunogloblin in a critically ill patient with 2019 novel coronavirus infection. Int. J. Antimicrob. Agents 2020, 105974. [CrossRef] [PubMed]

197. Shao, Z.; Feng, Y.; Zhong, L.; Xie, Q.; Lei, M.; Liu, Z.; Wang, C.; Ji, J.; Li, W.; Liu, H.; et al. Clinical Efficacy of Intravenous Immunoglobulin Therapy in Critical Patients with COVID-19: A Multicenter Retrospective Cohort Study. SSRN Electron. J. 2020. [CrossRef]

198. Xie, Y.; Cao, S.; Dong, H.; Li, Q.; Chen, E.; Zhang, W.; Yang, L.; Fu, S.; Wang, R. Effect of regular intravenous immunoglobulin therapy on prognosis of severe pneumonia in patients with COVID-19. J. Infect. 2020. [CrossRef]

199. Shanmugaraj, B.; Siriwattananon, K.; Wangkanont, K.; Phoolcharoen, W. Perspectives on monoclonal antibody therapy as potential therapeutic intervention for Coronavirus disease-19 (COVID-19). Asian Pac. J. Allergy Immunol. 2020, 38, 10-18. [CrossRef]

200. Fu, B.; Xu, X.; Wei, H. Why tocilizumab could be an effective treatment for severe COVID-19? J. Transl. Med. 2020, 18, 1-5. [CrossRef]

201. Du, Y.-X.; Chen, X.-P. Favipiravir: Pharmacokinetics and Concerns about Clinical Trials for 2019-nCoV Infection. Clin. Pharmacol. Ther. 2020. [CrossRef]

202. Choy, E.; Freemantle, N.; Proudfoot, C.; Chen, C.-I.; Pollissard, L.; Kuznik, A.; Van Hoogstraten, H.; Mangan, E.; Carita, P.; Huynh, T.-M.-T. Evaluation of the efficacy and safety of sarilumab combination therapy in patients with rheumatoid arthritis with inadequate response to conventional disease-modifying antirheumatic drugs or tumour necrosis factor $\alpha$ inhibitors: Systematic literature review and network meta-analyses. RMD Open 2019, 5, e000798. [CrossRef]

203. Berkhout, L.C.; L'Ami, M.J.; Ruwaard, J.; Hart, M.H.; Heer, P.O.-D.; Bloem, K.; Nurmohamed, M.T.; Van Vollenhoven, R.F.; Boers, M.; Alvarez, D.F.; et al. Dynamics of circulating TNF during adalimumab treatment using a drug-tolerant TNF assay. Sci. Transl. Med. 2019, 11, eaat3356. [CrossRef] [PubMed]

204. Markham, A. Baricitinib: First Global Approval. Drugs 2017, 184, 5298-5704. [CrossRef] [PubMed]

205. Praveen, D.; Chowdary, P.R.; Aanandhi, M. Baricitinib-a januase kinase inhibitor-not an ideal option for management of covid 19. Int. J. Antimicrobial Agents 2020. [CrossRef] [PubMed]

206. Nie, J.; Wang, C.; Liu, Y.; Yang, Q.; Mei, Q.; Dong, L.; Li, X.; Liu, J.; Ku, W.; Zhang, Y.; et al. Addition of Low-Dose Decitabine to Anti-PD-1 Antibody Camrelizumab in Relapsed/Refractory Classical Hodgkin Lymphoma. J. Clin. Oncol. 2019, 37, 1479-1489. [CrossRef] [PubMed]

207. Blair, H.A. Ibalizumab: A Review in Multidrug-Resistant HIV-1 Infection. Drugs 2020, 80, 189-196. [CrossRef] [PubMed]

208. Sehgal, S.; Velcheti, V.; Mukhopadhyay, S.; Stoller, J.K. Focal lung infiltrate complicating PD-1 inhibitor use: A new pattern of drug-associated lung toxicity? Respirat. Med. Rep. 2016, 19, 118-120. [CrossRef]

209. Wang, Z.; Chen, T.; Lin, W.; Zheng, W.; Chen, J.; Huang, F.; Xie, X. Functional tumor specific CD 8 + T cells in spleen express a high level of PD-1. Int. Immunopharmacol. 2020, 80, 106242. [CrossRef]

210. Wang, C.; Rademaker, M.; Baker, C.; Foley, P. COVID-19 and the use of immunomodulatory and biologic agents for severe cutaneous disease: An Australia/New Zealand consensus statement. Austral. J. Dermatol. 2020. [CrossRef]

211. De Luca, G.; Cavalli, G.; Campochiaro, C.; Della-Torre, E.; Angelillo, P.; Tomelleri, A.; Boffini, N.; Tentori, S.; Mette, F.; Farina, N.; et al. GM-CSF blockade with mavrilimumab in severe COVID-19 pneumonia and systemic hyperinflammation: A single-centre, prospective cohort study. Lancet Rheumatol. 2020. [CrossRef]

212. Jiang, S.; Hillyer, C.; Du, L.J.T. Neutralizing antibodies against SARS-CoV-2 and other human coronaviruses. Trends Immunol. 2020, 41, 355-359. [CrossRef]

213. Pinto, D.; Park, Y.J.; Beltramello, M.; Walls, A.C.; Tortorici, M.A.; Bianchi, S.; Jaconi, S.; Culap, K.; Zatta, F.; De Marco, A.; et al. Cross-neutralization of SARS-CoV-2 by a human monoclonal SARS-CoV antibody. Nature 2020, 583, 1-6. [CrossRef] [PubMed]

214. Wang, C.; Li, W.; Drabek, D.; Okba, N.M.; Van Haperen, R.; Osterhaus, A.D.M.E.; Van Kuppeveld, F.J.M.; Haagmans, B.L.; Grosveld, F.; Bosch, B.J. A human monoclonal antibody blocking SARS-CoV-2 infection. Nat. Commun. 2020, 11, 2251-2256. [CrossRef] [PubMed] 
215. Wu, Y.; Wang, F.; Shen, C.; Peng, W.; Li, D.; Zhao, C.; Li, Z.; Li, S.; Bi, Y.; Yang, Y.; et al. A noncompeting pair of human neutralizing antibodies block COVID-19 virus binding to its receptor ACE2. Science 2020, 368, 1274-1278. [CrossRef] [PubMed]

216. Sweiti, H.; Ekwunife, O.; Jaschinski, T.; Lhachimi, S.K. Repurposed Therapeutic Agents Targeting the Ebola Virus: A Systematic Review. Curr. Ther. Res. 2017, 84, 10-21. [CrossRef] [PubMed]

217. Gielen, V.; Johnston, S.L.; Edwards, M.R. Azithromycin induces anti-viral responses in bronchial epithelial cells. Eur. Respir. J. 2010, 36, 646-654. [CrossRef]

218. Li, C.; Zu, S.; Deng, Y.-Q.; Li, D.; Parvatiyar, K.; Quanquin, N.; Shang, J.; Sun, N.; Su, J.; Liu, Z.; et al. Azithromycin Protects against Zika Virus Infection by Upregulating Virus-Induced Type I and III Interferon Responses. Antimicrob. Agents Chemother. 2019, 63. [CrossRef]

219. Tran, D.H.; Sugamata, R.; Hirose, T.; Suzuki, S.; Noguchi, Y.; Sugawara, A.; Ito, F.; Yamamoto, T.; Kawachi, S.; Akagawa, K.S.; et al. Azithromycin, a 15-membered macrolide antibiotic, inhibits influenza A(H1N1)pdm09 virus infection by interfering with virus internalization process. J. Antibiot. 2019, 72, 759-768. [CrossRef]

220. Barnes, P.J. How corticosteroids control inflammation: Quintiles Prize Lecture 2005. Br. J. Pharmacol. 2009, 148, 245-254. [CrossRef]

221. Stern, A.; Skalsky, K.; Avni, T.; Carrara, E.; Leibovici, L.; Paul, M. Corticosteroids for pneumonia. Cochrane Database Syst. Rev. 2017, 2017, CD007720. [CrossRef]

222. Wang, D.; Hu, B.; Hu, C.; Zhu, F.; Liu, X.; Zhang, J.; Wang, B.; Xiang, H.; Cheng, Z.; Xiong, Y.; et al. Clinical Characteristics of 138 Hospitalized Patients With 2019 Novel Coronavirus-Infected Pneumonia in Wuhan, China. JAMA 2020, 323, 1061. [CrossRef] [PubMed]

223. Rodrigo, C.; Leonardi-Bee, J.; Nguyen-Van-Tam, J.; Lim, W.S. Effect of Corticosteroid Therapy on Influenza-Related Mortality: A Systematic Review and Meta-analysis. J. Infect. Dis. 2014, 212, 183-194. [CrossRef] [PubMed]

224. Arabi, Y.; Mandourah, Y.; Al-Hameed, F.; Sindi, A.A.; Almekhlafi, G.A.; Hussein, M.; Jose, J.; Pinto, R.; Al-Omari, A.; Kharaba, A.; et al. Corticosteroid Therapy for Critically Ill Patients with Middle East Respiratory Syndrome. Am. J. Respir. Crit. Care Med. 2018, 197, 757-767. [CrossRef] [PubMed]

225. Yang, Z.; Liu, J.; Zhou, Y.; Zhao, X.; Zhao, Q.; Liu, J. The effect of corticosteroid treatment on patients with coronavirus infection: A systematic review and meta-analysis. J. Infect. 2020, 81, e13-e20. [CrossRef]

226. Zha, L.; Li, S.; Pan, L.; Tefsen, B.; Li, Y.; French, N.; Chen, L.; Yang, G.; Villanueva, E.V. Corticosteroid treatment of patients with coronavirus disease 2019 (COVID -19). Med. J. Aust. 2020, 212, 416-420. [CrossRef]

227. Fang, X.; Mei, Q.; Yang, T.; Li, L.; Wang, Y.; Tong, F.; Geng, S.; Pan, A. Low-dose corticosteroid therapy does not delay viral clearance in patients with COVID-19. J. Infect. 2020. [CrossRef]

228. World Health Organization Clinical management of severe acute respiratory infection (SARI) when COVID-19 disease is suspected. Interim guidance. Pediatr. Med. Rodz. 2020, 16, 9-26. [CrossRef]

229. Ledford, H. Coronavirus breakthrough: Dexamethasone is first drug shown to save lives. Nature 2020, $582,469$. [CrossRef] [PubMed]

230. Horby, P.; Lim, W.S.; Emberson, J.; Mafham, M.; Bell, J.; Linsell, L.; Staplin, N.; Brightling, C.; Ustianowski, A.; Elmahi, E.; et al. Effect of Dexamethasone in Hospitalized Patients with COVID-19: Preliminary Report. medRxiv 2020. [CrossRef]

231. Gewaltig, M.T.; Kojda, G. Vasoprotection by nitric oxide: Mechanisms and therapeutic potential. Cardiovasc. Res. 2002, 55, 250-260. [CrossRef]

232. Åkerstroöm, S.; Mousavi-Jazi, M.; Klingstrom, J.; Leijon, M.; Lundkvist, A.; Mirazimi, A. Nitric Oxide Inhibits the Replication Cycle of Severe Acute Respiratory Syndrome Coronavirus. J. Virol. 2005, 79, 1966-1969. [CrossRef]

233. Keyaerts, E.; Vijgen, L.; Chen, L.; Maes, P.; Hedenstierna, G.; Van Ranst, M. Inhibition of SARS-coronavirus infection in vitro by S-nitroso-N-acetylpenicillamine, a nitric oxide donor compound. Int. J. Infect. Dis. 2004, 8, 223-226. [CrossRef] [PubMed]

234. Dellinger, R.P.; Trzeciak, S.; Criner, G.; Zimmerman, J.L.; Taylor, R.W.; Usansky, H.; Young, J.; Goldstein, B. Association between inhaled nitric oxide treatment and long-term pulmonary function in survivors of acute respiratory distress syndrome. Crit. Care 2012, 16, R36. [CrossRef] [PubMed]

235. Åkerström, S.; Gunalan, V.; Keng, C.T.; Tan, Y.-J.; Mirazimi, A. Dual effect of nitric oxide on SARS-CoV replication: Viral RNA production and palmitoylation of the S protein are affected. Virology 2009, 395, 1-9. [CrossRef] 
236. Chen, L.; Liu, P.; Gao, H.; Sun, B.; Chao, D.; Wang, F.; Zhu, Y.; Hedenstierna, G.; Wang, C.G. Inhalation of Nitric Oxide in the Treatment of Severe Acute Respiratory Syndrome: A Rescue Trial in Beijing. Clin. Infect. Dis. 2004, 39, 1531-1535. [CrossRef]

237. Kakodkar, P.; Kaka, N.; Baig, M. A Comprehensive Literature Review on the Clinical Presentation, and Management of the Pandemic Coronavirus Disease 2019 (COVID-19). Cureus 2020, 12. [CrossRef]

238. Dong, L.; Hu, S.; Gao, J. Discovering drugs to treat coronavirus disease 2019 (COVID-19). Drug Discov. Ther. 2020, 14, 58-60. [CrossRef]

239. Sanders, J.M.; Monogue, M.L.; Jodlowski, T.Z.; Cutrell, J.B. Pharmacologic Treatments for Coronavirus Disease 2019 (COVID-19): A Review. JAMA 2020. [CrossRef]

240. Uno, Y. Camostat mesilate therapy for COVID-19. Intern. Emerg. Med. 2020, 2020, 1-2. [CrossRef]

241. Zhang, J.; Yang, Y.; Yang, N.; Ma, Y.; Zhou, Q.; Li, W.; Wang, X.; Huang, L.; Luo, X.; Fukuoka, T.; et al. Effectiveness of intravenous immunoglobulin for children with severe COVID-19: A rapid review. Ann. Transl. Med. 2020, 8, 625. [CrossRef]

242. Bray, M.; Rayner, C.; Noël, F.; Jans, D.; Wagstaff, K. Ivermectin and COVID-19: A report in Antiviral Research, widespread interest, an FDA warning, two letters to the editor and the authors' responses. Antivir. Res. 2020, 178, 104805. [CrossRef] [PubMed]

243. NIH COVID-19 Treatment Guidelines, Corticosteroids (Including Dexamethasone) [Internet]. 17 July 2020. Available online: https:/www.covid19treatmentguidelines.nih.gov/immune-based-therapy/immunomodulators/ corticosteroids/\&lt;monospace\&gt;\&lt;/monospace\&gt; (accessed on 30 July 2020).

(C) 2020 by the authors. Licensee MDPI, Basel, Switzerland. This article is an open access article distributed under the terms and conditions of the Creative Commons Attribution (CC BY) license (http://creativecommons.org/licenses/by/4.0/). 